Article

\title{
Clarifying the Role of the Reducers-to-Oxidizers Ratio in the Solution Combustion Synthesis of $\mathrm{Ba}_{0.5} \mathrm{Sr}_{0.5} \mathrm{Co}_{0.8} \mathrm{Fe}_{0.2} \mathrm{O}_{3-\delta}$ Oxygen Electrocatalysts
}

\author{
Francesca Deganello ${ }^{1, *(\mathbb{D})}$, Leonarda F. Liotta ${ }^{1}\left(\mathbb{D}\right.$, Chiara Aliotta $^{1}$, Antonio Barbucci ${ }^{2,3}{ }^{\circledR}$, \\ Massimo Viviani ${ }^{2}\left(\mathbb{D}\right.$, Davide Clematis ${ }^{3}\left(\mathbb{D}\right.$, Maria Paola Carpanese ${ }^{2,3}$ and Sabrina Presto ${ }^{2}(\mathbb{D})$ \\ 1 Istituto per lo Studio dei Materiali Nanostrutturati (ISMN)—Consiglio Nazionale delle Ricerche (CNR), \\ Via Ugo La Malfa 153, 90146 Palermo, Italy; leonardafrancesca.liotta@cnr.it (L.F.L.); \\ chiara.aliotta@alice.it (C.A.) \\ 2 Istituto di Chimica della Materia Condensata e di Tecnologie per l'Energia (ICMATE)—Consiglio Nazionale \\ delle Ricerche (CNR), c/o DICCA-UNIGE, Via all'Opera Pia 15, 16145 Genova, Italy; barbucci@unige.it (A.B.); \\ massimo.viviani@cnr.it (M.V.); carpanese@unige.it (M.P.C.); sabrina.presto@cnr.it (S.P.) \\ 3 Dipartimento di Ingegneria Civile, Chimica e Ambientale (DICCA)-Università di Genova (UNIGE), \\ Via all'Opera Pia 15, 16145 Genova, Italy; davide.clematis@edu.unige.it \\ * Correspondence: francesca.deganello@cnr.it; Tel.: +39-091-680-9387
}

Received: 30 November 2020; Accepted: 12 December 2020; Published: 15 December 2020

\begin{abstract}
Ba}_{0.5} \mathrm{Sr}_{0.5} \mathrm{Co}_{0.8} \mathrm{Fe}_{0.2} \mathrm{O}_{3-\delta}$ perovskite-type compounds are well-known mixed ionic-electronic conductors for oxygen electrocatalytic applications, although their performance is strictly dependent on the selected preparation methodology and processing parameters. The reducers-to-oxidizers ratio $(\Phi)$ is a very important parameter in the solution combustion synthesis of mixed ionic-electronic conductors. Selection of $\Phi$ is not trivial and it strongly depends on the type of fuel used, the chemical composition and the specific application of the material. This work clarifies the role of $\Phi$ in the solution combustion synthesis of $\mathrm{Ba}_{0.5} \mathrm{Sr}_{0.5} \mathrm{Co}_{0.8} \mathrm{Fe}_{0.2} \mathrm{O}_{3-\delta}$ for application as oxygen electrocatalysts. $\mathrm{Ba}_{0.5} \mathrm{Sr}_{0.5} \mathrm{Co}_{0.8} \mathrm{Fe}_{0.2} \mathrm{O}_{3-\delta}$ powders were synthesized by solution combustion synthesis using sucrose-polyethylene glycol fuel mixtures with reducers-to-oxidizers ratio values between 1 (stoichiometric) and 3 (over-stoichiometric). Chemical-physical properties were studied by $\mathrm{X}$-ray diffraction, scanning electron microscopy, $\mathrm{N}_{2}$ adsorption at $-196{ }^{\circ} \mathrm{C}, \mathrm{H}_{2}$-temperature programmed reduction and thermogravimetric analysis. The results evidenced the direct role of $\Phi$ on the intensity and redox environment of the combustion process, and its indirect influence on the $\mathrm{Ba}_{0.5} \mathrm{Sr}_{0.5} \mathrm{Co}_{0.8} \mathrm{Fe}_{0.2} \mathrm{O}_{3-\delta}$ electrode materials properties. Taking into account the general picture, the highly over-stoichiometric $\Phi$ was selected as the optimal one and the electrochemical activity of the corresponding powder was tested by electrochemical impedance spectroscopy on electrolyte-supported half-cells employing a $\mathrm{Ce}_{0.8} \mathrm{Sm}_{0.2} \mathrm{O}_{2-x}$ electrolyte.
\end{abstract}

Keywords: solution combustion synthesis; sucrose-polyethylene glycol fuel mixture; reducers-to-oxidizers ratio; electrode materials; perovskite-type compounds; $\mathrm{Ba}_{0.5} \mathrm{Sr}_{0.5} \mathrm{Co}_{0.8} \mathrm{Fe}_{0.2} \mathrm{O}_{3-\delta}$; solid oxide fuel cells; temperature programmed reduction; powder $\mathrm{X}$-ray diffraction; Rietveld refinement

\section{Introduction}

Electrocatalytic materials for the oxygen reduction reaction are fundamental components in clean energy production/accumulation devices [1]. They need to be mixed ionic-electronic conductors able to transfer charges at the gas-solid interface and to drift oxygen vacancies in the bulk in order to allow the redox reaction $\mathrm{O}_{2}+2 \mathrm{e}^{-}=\mathrm{O}^{2-}[2-5]$. $\mathrm{Ba}_{0.5} \mathrm{Sr}_{0.5} \mathrm{Co}_{0.8} \mathrm{Fe}_{0.2} \mathrm{O}_{3-\delta}$ (BSCF) is a well-known perovskite-type 
mixed ionic-electronic conductor with fast oxygen exchange reaction and large bulk conductivity, able to keep a considerable oxygen deficiency in its cubic structure, without transforming into a vacancy-ordered structure $[3,6,7]$. The large affinity of BSCF for oxygen was initially exploited for its application in oxygen separation membranes, since high oxygen permeation was generated by its considerable oxygen vacancy concentration [8,9]. Later on, in 2004, BSCF was also proposed as a new and compelling cathode material for Solid Oxide Fuel Cells (SOFC), in view of its oxygen affinity and mixed ionic-electronic conductivity [10]. In addition, BSCF-based compositions were intensively studied as metal-air batteries oxygen electrocatalysts materials for oxygen reduction/evolution reactions [11-13]. With the increasing interest to develop reversible electrochemical systems, BSCF has also been studied as a constituent of the anode in solid oxide electrolysis cells (SOEC) [14], as well as in cells with proton conducting electrolytes $[15,16]$ thanks to its proton-conduction potential due to its significant hydration ability, especially when doped with an alkaline element [17].

BSCF cathode materials commonly suffer of poor structural stability [18-21] and low $\mathrm{CO}_{2}$ tolerance [22]. Therefore, several studies have been dedicated to a fine tailoring of structural, microstructural and textural features of BSCF-based powders, with the aim to improve their electrocatalytic performance and stability [23-31]. Doping of BSCF can be another option to enhance both activity and stability of BSCF cathode materials [32]. Other literature studies have been more focused on the post-synthesis and processing procedures like impregnation with another perovskite-type cathode material $[19,33]$, preparation of asymmetric structures [34] or association of dense and porous layers $[35,36]$. Scientists generally agree on that the performance of BSCF as ORR electrode material is strongly related to the cobalt environment and oxidation state, which is further related to the oxygen vacancies [12,13,23]. For example, in 2013, Deganello et al. [23] found a clear relationship between the area specific resistance (ASR) of a BSCF cathode material prepared by solution combustion synthesis and the amount of $\mathrm{Co}^{2+}$ in the perovskite-type structure. Similar conclusions were reached by Liu et al. [37] for other cobalt-containing electrocatalysts, evidencing the importance of an octahedral $\mathrm{Co}^{2+}$ coordination for a better oxygen reduction reaction performance. Stabilization of lower Co oxidation states in BSCF has been found to also be very important in oxygen evolution reactions [38]. The cited literature studies clearly suggest that a certain control of cobalt environment is possible through synthesis optimization of BSCF powders. Solution combustion synthesis (SCS) is a powerful and versatile tool for the synthesis of multicomponent mixed oxides powders with controlled properties $[39,40]$. By changing the synthesis parameters, SCS allows optimization and control of the materials properties and performance, as long as the relationships between these parameters and the final powder are known [39]. The fuel-related parameters are among the most important ones, affecting phase purity, microstructure, morphology and defectivity [39,41-43]. A variety of fuels has been proposed for the solution combustion synthesis of BSCF mixed oxides [13,44,45]. Regarding the effect of fuel amount, it can be studied in terms of (i) the reducers-to-oxidizer ratio, $\Phi$, which takes into account the reducing properties of the fuel, or (ii) the fuel-to-metal cations ratio, $\mathrm{F} / \mathrm{M}$, which takes into account the chelating properties of the fuel toward the metal precursors used as element source [39]. Both these parameters are important for a better comprehension of the synthesis-structure-properties relationships, having a different role in the process, and thus they should be considered separately [39]. The effect of $\Phi$ in the powder properties of mixed oxide and metal oxide-based powders prepared by SCS has been investigated in the literature for a variety of chemical compositions $[41,46,47]$. Disregarding the chemical composition considered, two generally accepted conclusions about the $\Phi$ effect on the powder properties are that (i) higher $\Phi$ values correspond to a more reducible environment during the synthesis, and (ii) the carbon content in the as-burned powders increases by increasing $\Phi[42,46]$. However, the effect of $\Phi$ on the materials properties is still not clear, and different results have also been reported [48-52]. This apparent divergence is likely due to the different experimental conditions used and to the different chemical composition of the studied samples [39]. In fact, $\Phi$ is able to influence several features of the combustion process itself, like the combustion temperature and duration of the process, and the importance of each feature 
in the structural, microstructural, morphological and textural properties of the obtained materials depends both on chemical composition, type of fuel and type of technological application [39,47,52]. Furthermore, the effect of experimental conditions may affect differently the products depending on the fuel used. For example, the contribution of the atmospheric oxygen gas in the combustion process has been found to affect the phase composition of the as-burned powders as a function of the fuel type [53]. Finally, the difference in the reducers-to-oxidizers range examined in each literature work could be discriminating. A short range might be not sufficient for big changes, but a wider range might overlook some intermediate trends. Usually, the $\Phi$ range studied is from 0.5 to about 2 , but some literature works examined a much wider range $[48,52,54]$. The effect of $\Phi$ has been also studied for perovskite-type compounds prepared by SCS $[49,51,52,55,56]$, but, to our knowledge, it has been rarely investigated for perovskite-type cathode materials for application in electrochemical devices [57].

This work aims at clarifying the role of the reducers-to-oxidizers ratio in the solution combustion synthesis of $\mathrm{Ba}_{0.5} \mathrm{Sr}_{0.5} \mathrm{Co}_{0.8} \mathrm{Fe}_{0.2} \mathrm{O}_{3-\delta}$ electrocatalysts, through a systematic study of the $\Phi$ effect in the structural, redox and microstructural properties of the investigated materials in relation to their use as cathode materials for clean energy production-related electrochemical applications. $\mathrm{Ba}_{0.5} \mathrm{Sr}_{0.5} \mathrm{Co}_{0.8} \mathrm{Fe}_{0.2} \mathrm{O}_{3-\delta}$ powders with stoichiometric and over-stoichiometric $\Phi$ values were prepared by solution combustion synthesis by using a sucrose-PEG fuel mixture. The fuel-to-metal cations ratio was kept constant and the $\Phi$ ratio was regulated at 1,1.7, 2.2 and 3.1 by the addition of suitable amounts of ammonium nitrate. The effect of the $\Phi$ on the physical-chemical properties of prepared materials was evaluated by using complementary characterization techniques. The choice of a sucrose-PEG fuel mixture is supported by the results obtained in a previous work by Deganello et al. [23]. In that work, fuel mixtures with high reducing power and high interaction with metal cations, like sucrose-PEG ones, were found to stabilize $\mathrm{Co}^{2+}$ at the B-site of the BSCF prepared by SCS and to increase its oxygen defectivity [23].

\section{Results}

\subsection{The Combustion Process and the As-Burned Powders}

On the basis of visual observation, the combustion process for all the BSCF samples was fast, intense and with an evident flame (Figure 1a). A definite peak in the temperature/time profile within the time frame of seconds is closely related to a self-sustaining combustion reaction.

The three most meaningful features to observe in any temperature/time profile are: (i) the ignition of the combustion reaction, indicative of the beginning of the process; (ii) the maximum of the temperature/time peak, showing the highest temperature reached by the combustion reaction; and (iii) the peak width, often used in the literature to give an indication on the duration of the entire process [58] (Figure 1a). High maximum temperature of the combustion peak and small duration correspond to an intense combustion reaction. Figure $1 \mathrm{~b}$ reports temperature/time profiles registered during the combustion processes. The duration of the combustion process of BSCF31 (sample with the highest $\Phi$ ) was longer than for the others. It appears immediately evident that BSCF10, BSCF17 and BSCF22 show a single combustion peak, with a maximum temperature in the $700-800{ }^{\circ} \mathrm{C}$ range, whereas BSCF31 exhibits a slightly lower maximum temperature and an enlarged peak with two nearby maxima (Figure 1b). Therefore, a $\Phi$ value of 3.1 still falls inside the combustion regime, although it makes the combustion process slower and more mild. Ignition temperature occurs below $150{ }^{\circ} \mathrm{C}$ for all the investigated samples and is essentially related to the type of fuel mixture. Regarding the maximum temperature, a volcano-type trend as a function of $\Phi$ was observed (Figure 1c). According to Figure 1c, the highest temperature of the combustion process corresponds to a $\Phi$ of about 2 . A volcano trend of the maximum temperature with $\Phi$ is not surprising, since similar trends have been found in the literature, although in this work the volcano curve is centered at higher $\Phi$ values than in the literature. For example, S.S. Ail et al. [46] investigated single and mixed oxides with different composition in a different reducers-to-oxidizers ratio range. They found that the maximum 
temperature of the combustion process, in the synthesis of alumina-supported cobalt oxides for Fischer Tropsch applications, occurred for a stoichiometric $\Phi$ value. In fact, it is known that the adiabatic temperature of a combustion process is at its maximum at the stoichiometric $\Phi$ value and decreases at lower and higher $\Phi$ values $[39,40]$. A shift in the volcano maximum may be due to differences in chemical composition of the fuel mixture, combustion set-up, reducers-to-oxidizers range considered, and other experimental conditions. Indeed, in practical experiments, where the combustion process is not fully adiabatic (due to a certain heat dispersion), the maximum temperature of the process might be slightly shifted toward higher $\Phi$ values $[39,40]$. The shift in the $\Phi$ ratio is more pronounced for a slower combustion process, where the adiabatic character is less prominent and the oxygen from the environment plays a fundamental role [53]. Moreover, it is also necessary to take into account the simultaneous variation of two important fuel amount-related parameters, i.e., reducers-to-oxidizers ratio and fuel-to-metal cations ratio. In this work, all the parameters were maintained strictly constant, and only the $\Phi$ was varied through the addition of decreasing amounts of ammonium nitrate from BSCF10 to BSCF31 (see Materials and Methods). None of the as-burned powders did contain the perovskite phase (Figure 1d).
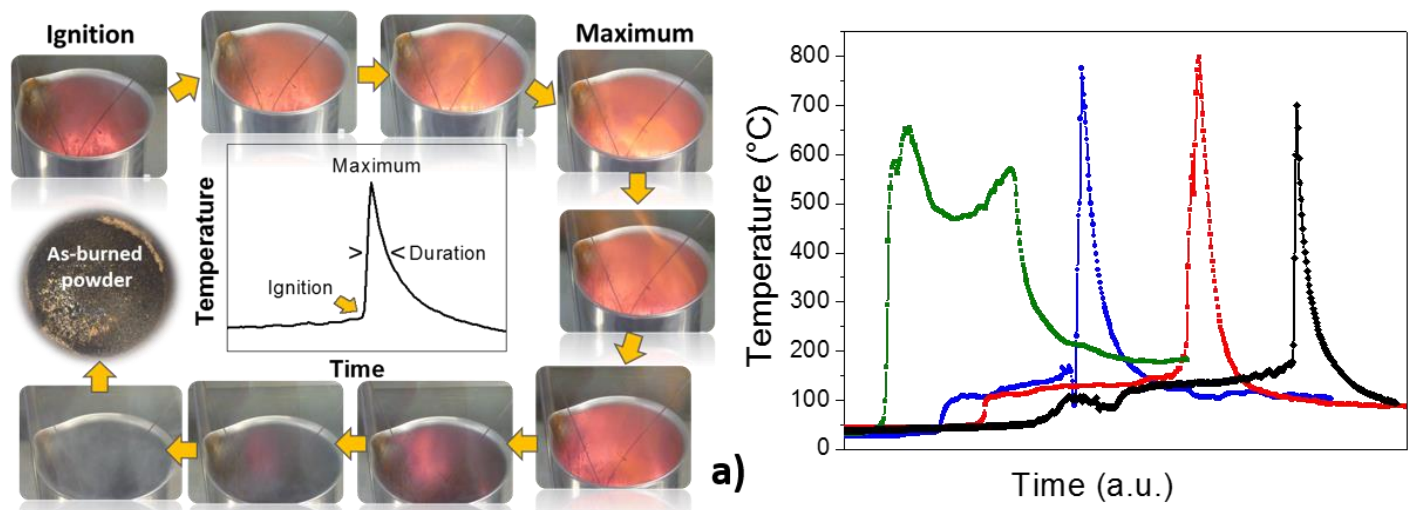

b)
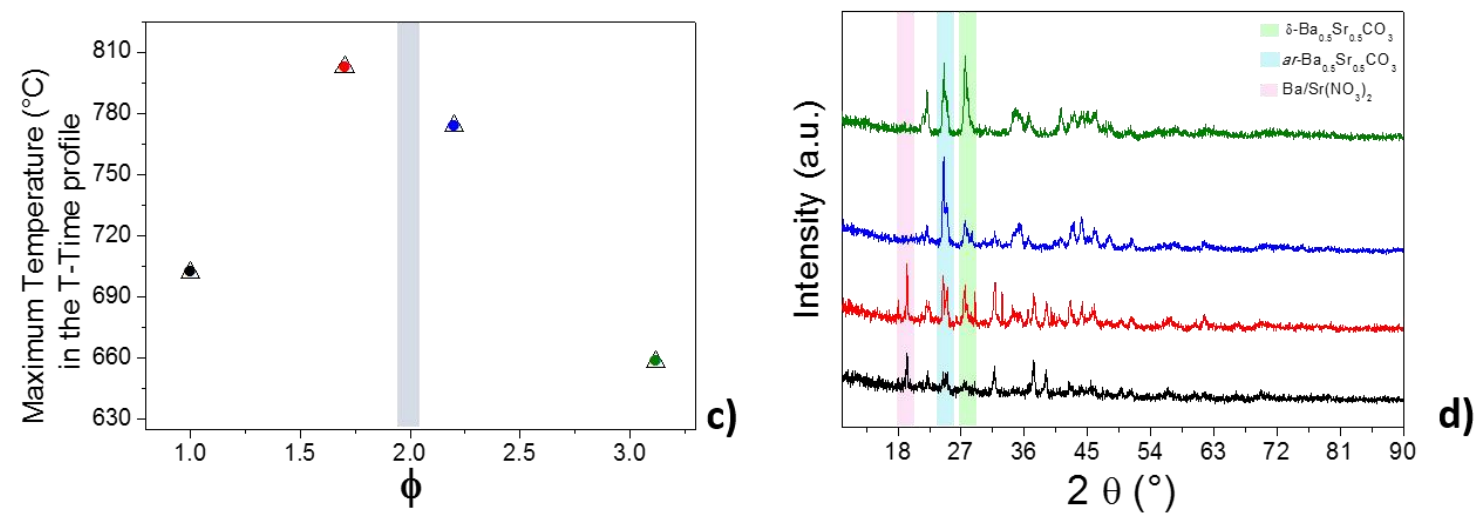

Figure 1. (a) Sequential pictures of a typical combustion process of a BSCF prepared by SCS from a sucrose-PEG 20,000 mixture leading toward the as-burned powder, showing the three most meaningful features of a temperature/time profile; (b) comparison between temperature/time profiles registered for BSCF10 (black), BSCF17 (red), BSCF22 (blue) and BSCF31 (green); (c) volcano-type trend of the maximum temperature in the temperature/time profiles as a function of $\Phi$; (d) XRD patterns of as-burned BSCF10 (black), BSCF17 (red), BSCF22 (blue) and BSCF31 (green). Colored rectangles evidence the main peak of the three $\mathrm{Ba} / \mathrm{Sr}$-containing intermediate phases.

The XRD patterns of the as-burned powders evidenced the presence of mixed Ba-Sr carbonates (with aragonite and $\delta$-type structure), a Co-Fe spinel phase and traces of metallic cobalt, in agreement with a previous paper [23]. Peaks ascribable to Ba/Sr nitrates were also detected in BSCF10 and BSCF17 (Figure 1d), probably due to the locally incomplete combustion occurring for a combustion mixture with 
high amount of additional oxidant (see Materials and Methods). The delta-type ( $\delta$ ) and aragonite-type (ar) mixed Ba/Sr carbonates increased from BSCF10 to BSCF31, at the expense of the Ba/Sr nitrate phases (Figure 1d). The highest amount of $\delta$ phase with respect to aragonite phase was detected in the BSCF as-burned powder with the least intense combustion process (low maximum temperature and high duration of the process) (see Figure 1b). This is in agreement with what was reported in a previous paper by Deganello et al., where the amount of $\delta \mathrm{Ba} / \mathrm{Sr}$ carbonate phase, a metastable phase, depended very much on the overall intensity (maximum temperature and duration) of the combustion process [23]. The lack of perovskite phase in the XRD pattern of the as-burned powders is not surprising. In general, perovskite formation occurs at relatively high temperatures, between $700{ }^{\circ} \mathrm{C}$ and $1000^{\circ} \mathrm{C}$, although this depends strongly on the chemical composition and on the synthesis procedure. Higher alkaline earth content in the perovskite chemical composition usually shifts the perovskite phase formation to temperatures over $900^{\circ} \mathrm{C}$, due to the high thermal stability of alkaline earth carbonates. In particular, BSCF prepared by solution combustion synthesis are not formed directly in the as-burned powders, unless the temperature of the combustion process reaches $900-1000{ }^{\circ} \mathrm{C}$ for a reasonable time. In fact, the perovskite phase formed in the as-burned powders is often accompanied by secondary phases and reactants residuals. For example, Yusoff et al. [59] found the BSCF perovskite formation after a thermal treatment at $900^{\circ} \mathrm{C} / 5 \mathrm{~h}$. Nuernberg et al. evidenced for a series of BSCF a perovskite formation temperature range between $880^{\circ} \mathrm{C}$ and $920^{\circ} \mathrm{C}$, although they also mentioned some secondary phases beside the perovskite main phase [45]. Other literature works confirmed the high temperature formation of BSCF perovskite phases $[23,24,60]$.

\subsection{Structure, Microstructure and Texture after Further Thermal Treatments}

The thermal treatment of the as-burned powders at $950{ }^{\circ} \mathrm{C}$ for $5 \mathrm{~h}$ in air led to the formation of the typical BSCF perovskite-type cubic structure refined in Pm-3m space group (ICDD database, PDF n $\left.{ }^{\circ} 00-055-0563\right)$, as shown for BSCF31 by the graphical Rietveld refinement results in Figure 2a,b. The main refined parameters are reported in Figure $2 b$ together with the reliability factors ( $R$ factors).

However, XRD patterns displayed in Figure 2c reveal that only BSCF31 is single-phase, whereas the other three samples contain a secondary phase with rhombohedral structure. The presence of hexagonal, trigonal and/or rhombohedral secondary phases in BSCF compounds has been frequently reported in the literature in relation to the limited stability of lower oxidation states at the B-site of the BSCF perovskite under oxidative conditions [61,62]. The secondary phase in the BSCF powders calcined at $950{ }^{\circ} \mathrm{C}$ decreases gradually from BSCF10 to BSCF31, until it disappears (Figure 2c), in agreement with the trends reported in the literature for perovskite-type compounds with different composition prepared by SCS [56]. Figure 2d, obtained from the quantitative Rietveld analysis of the XRD patterns, shows that the trend of the secondary phase amount with $\Phi$ is linear, suggesting for the first time a direct influence of $\Phi$ in the secondary phase formation of BSCF. The secondary phase observed in our XRD pattern was identified as a rhombohedral phase with a P $63 \mathrm{~m}$ c space group, similar to a barium strontium cobaltite of the type $\mathrm{Ba}_{4.01} \mathrm{Sr}_{3.99} \mathrm{Co}_{4} \mathrm{O}_{15}$ (ICSD n ${ }^{\circ}$ 290,489), but with a much larger unit cell volume $\left(820 \AA^{3}\right.$ vs $\left.806 \AA^{3}\right)$, possibly due to a different (smaller) Sr/Ba ratio in the structure. The graphical Rietveld fit of BSCF10 is reported in Figure 2e,f as a representative sample. According to Figure S1, secondary phase formation clearly affects the BSCF cubic cell parameter, especially for percentages higher than $10 \mathrm{wt}$. \%, where a decrease in the cell parameter of about $0.002 \AA$ was registered. This slight, but significant, volume contraction is presumably due to a change of composition in the main BSCF phase, which becomes richer in Fe (and probably also in Sr) with the increasing of the $\mathrm{Ba}$ and $\mathrm{Co}$ rich-rhombohedral phase percentage, in agreement with what reported in the literature for another related type of secondary phase (hexagonal) [62]. The phase composition of the corresponding as-burned powders reflected the phase composition differences observed after thermal treatment at $950{ }^{\circ} \mathrm{C}$ described in Figure 2. In fact, the perovskite phase increases and the secondary phase decreases in the calcined powders (cfr. Figures $1 \mathrm{~d}$ and $2 \mathrm{c}$ ). This result is in agreement with the active role of aragonite and $\delta$ phases in the formation of a pure perovskite phase after final 
calcination, as discussed in a previous paper [23]. Similar results were obtained by Nuernberg et al. [45] for BSCF prepared by microwave assisted SCS: calcined powders with pure perovskite phases were obtained when as-burned powders contained higher amount of aragonite and $\delta$ Ba-Sr carbonate phases. TGA under air of BSCF17, BSCF22 and BSCF31 as-burned powders, presented in Figure S2, confirmed the XRD results. In fact, the black dashed line in the figure evidence progressive increase of the BSCF perovskite formation temperature from BSCF17 to BSCF31.
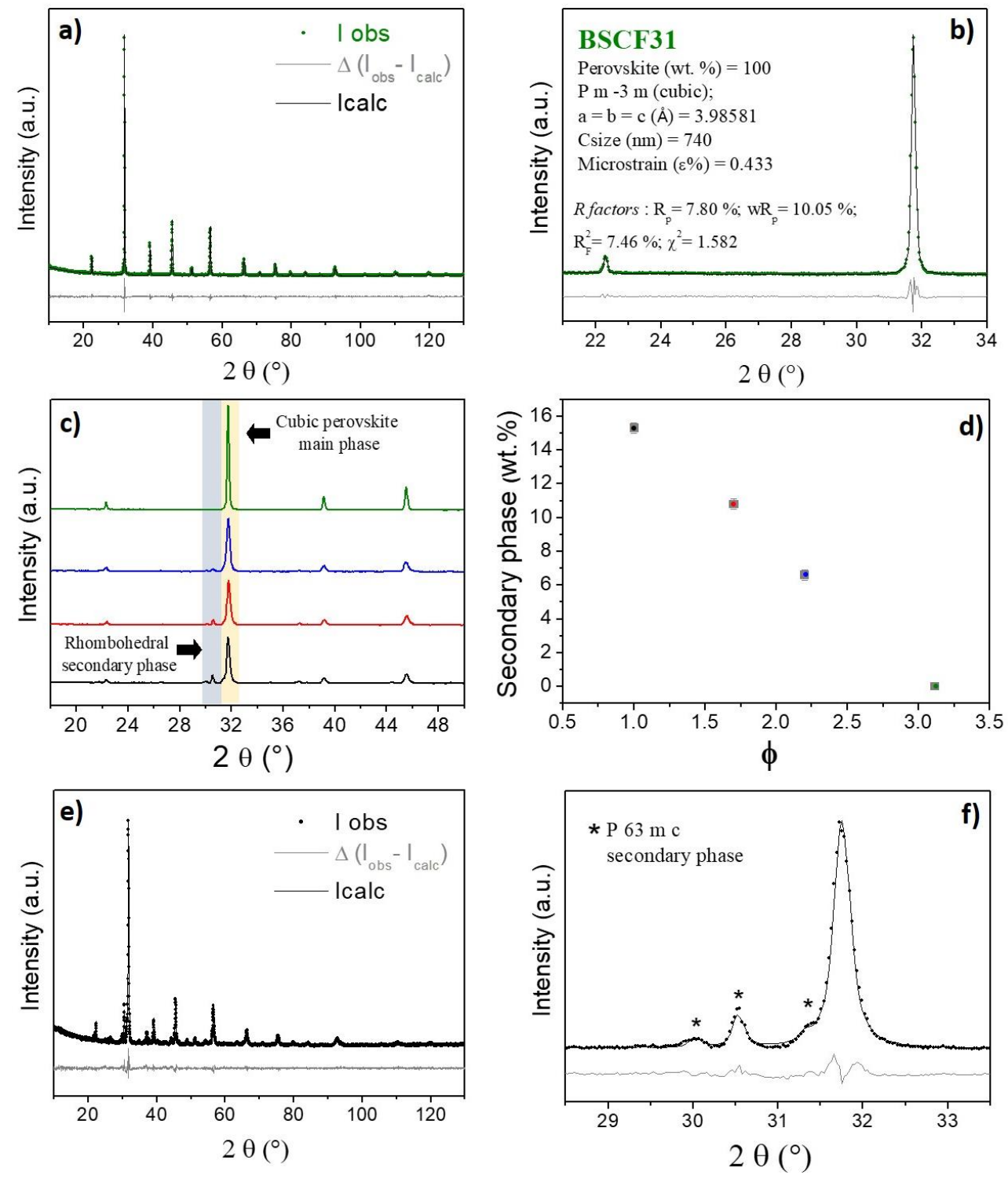

Figure 2. (a) Rietveld refinement of the XRD pattern of BSCF31 after calcination at $950{ }^{\circ} \mathrm{C}$ for $5 \mathrm{~h}$ : XRD experimental data (green full circles), fitted data (black line) and residual (grey line); (b) inset showing the $21-34^{\circ} 2 \theta$ region, reliability factors and other structural parameters obtained from Rietveld analysis; (c) insets of the XRD patterns of BSCF10 (black), BSCF17 (red), BSCF22 (blue) and BSCF31 (green) thermally treated at $950{ }^{\circ} \mathrm{C} / 5 \mathrm{~h}$. Rectangles evidence the main peak of the perovskite (light orange) and secondary phase (dark grey); (d) linear trend of the secondary phase amount (wt. \%) with the reducers-to-oxidizers ratio; error bars are also indicated in the graph for each secondary phase percentage; (e) Rietveld refinement for BSCF10 treated at $950{ }^{\circ} \mathrm{C}$ : XRD data (black dots), model (black line) and residual (grey line); in the inset (f), the P $63 \mathrm{~m}$ c secondary phase is evidenced by asterisks and its refined cell parameters are $\mathrm{a}=\mathrm{b}=11.7063 \pm 0.0008 \AA, \mathrm{c}=6.9092 \pm 0.0007 \AA$ and $\alpha=\beta=90^{\circ} \gamma=120^{\circ}, \mathrm{V}=820.0 \pm 0.1 \AA^{3}$. 
After thermal treatment of the powders at $1100{ }^{\circ} \mathrm{C}$ for two hours in air, under the same conditions used for the deposition of the cathode powder onto the SDC electrolyte, BSCF17, BSCF22 and BSCF31 become single phase, whereas BSCF10 still contains traces of secondary phase (Figure 3a).
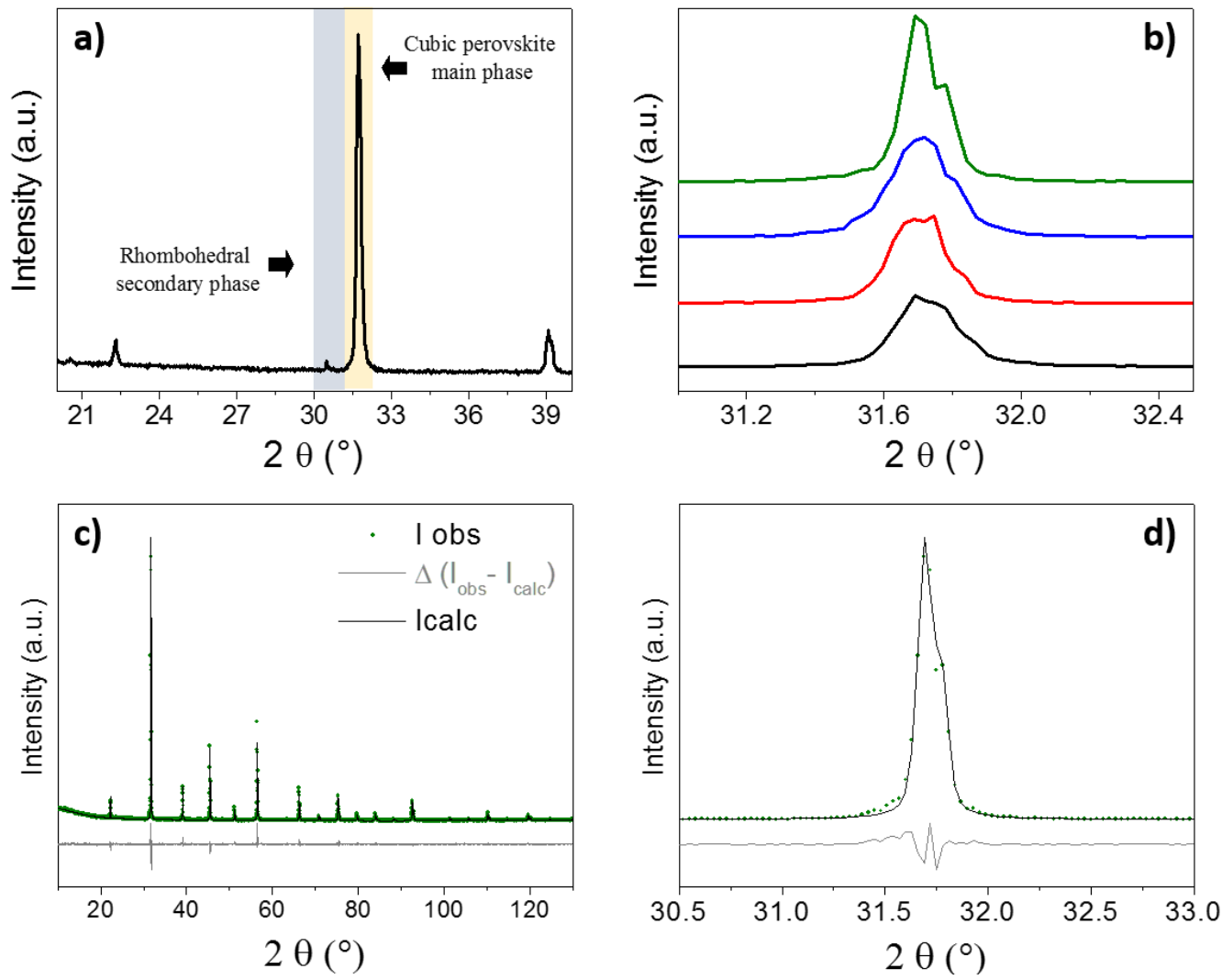

Figure 3. (a) Inset of the XRD pattern of BSCF10 after thermal treatment at $1100{ }^{\circ} \mathrm{C}$ for $2 \mathrm{~h}$; (b) inset of the perovskite phase's main peak in the 31-32.5 $2 \theta$ angular range of the XRD patterns of BSCF10 (black), BSCF17 (red), BSCF22 (blue) and BSCF31 (green) thermally treated at $1100^{\circ} \mathrm{C}$ for $2 \mathrm{~h}$; (c) Rietveld refinement of the XRD pattern of BSCF31 treated at $1100{ }^{\circ} \mathrm{C}$ for $2 \mathrm{~h}$ : XRD data (green dots), model (black line) and residual (grey line); (d) inset of the fitting in the region of the perovskite phase's main peak.

However, the main perovskite peak in Figure 3b appears wider in BSCF10, BSCF17 and BSCF22 and its shape changes from BSCF10 to BSCF31, indicating that symmetry is lower than in the cubic, and some distortion occurs in the structure of the three samples containing secondary phases before the thermal treatment at $1100{ }^{\circ} \mathrm{C}$ for $2 \mathrm{~h}$. This distortion could be ascribed to the influence of the secondary phase on the crystallization of the main phase during the thermal treatment. Therefore, any attempt to fit BSCF10, BSCF17 and BSCF22 with a Pm-3m cubic phase failed, and only the XRD pattern of BSCF31 was refined as a cubic structure. The Rietveld graphical fit obtained from the refinement of the BSCF31 single-phase pattern after thermal treatment at $1100{ }^{\circ} \mathrm{C}$ for $2 \mathrm{~h}$ is reported in Figure $3 \mathrm{c}, \mathrm{d}$.

SEM images of BSCF powders calcined at $950{ }^{\circ} \mathrm{C} / 4 \mathrm{~h}$ at increasing $\Phi$ ratio are reported in Figure 4. Grains are fused to each other, although single grains can be still recognized in all the samples. Powder microstructure and morphology varies with $\Phi$. The average grain size of the primary particles increases with $\Phi$ and the particle size distribution looks more homogeneous in BSCF10 and BSCF17 than in BSCF22 and BSCF31, where grains with small diameter $(1-2 \mu \mathrm{m})$ coexist with larger ones $(8-10 \mu \mathrm{m})$. Samples BSCF10 and BSCF17 show a high degree of grains agglomeration (further increased for BSCF17), which is significantly reduced in BSCF22 and even more in BSCF31. As a consequence, BSCF10 and BSCF17 present macropores in the range 1-10 $\mu \mathrm{m}$. In the calcined powders prepared using a stoichiometric $\Phi$ ratio, some porosity was present and grain size 
was relatively small (Figure 4). This is in agreement with the relatively low maximum temperature combined with the short duration of the combustion process (Figure $1 \mathrm{~b}, \mathrm{c}$ ). At the highest $\Phi$, a wider grain size distribution was obtained because of the larger combustion duration (Figures 4 and 1b). In other perovskite-type compositions, agglomeration and grain size has been reported to increase with $\Phi[52,63]$. In this work, the agglomeration degree changes with $\Phi$ as the intensity of the combustion process (see also Figure $1 \mathrm{~b}, \mathrm{c}$ ).

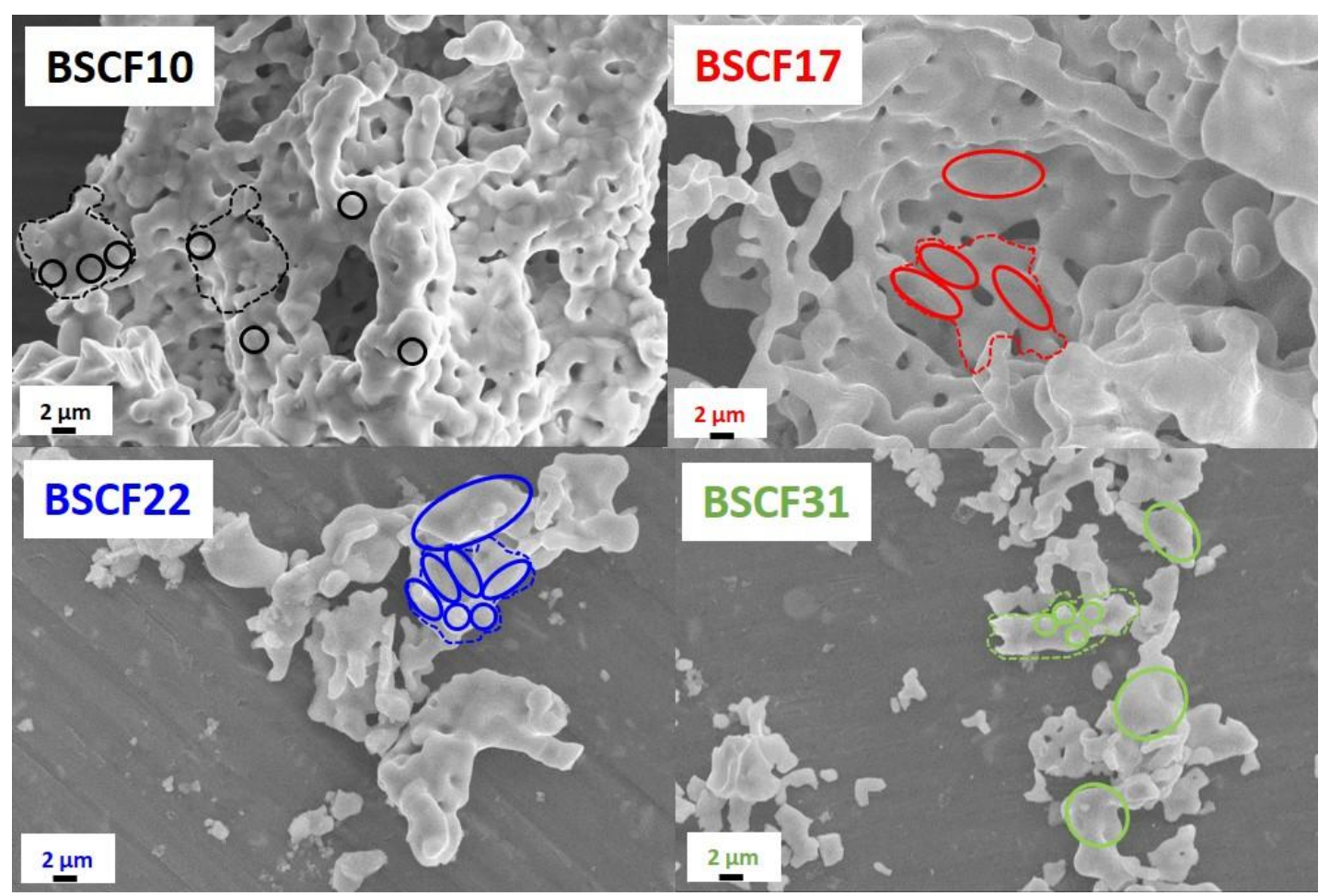

Figure 4. SEM images of the powders after thermal treatment at $950{ }^{\circ} \mathrm{C} / 5 \mathrm{~h}$ : BSCF10 (top, left), BSCF17 (top, right), BSCF22 (bottom, left) and BSCF31 (bottom, right). For each image, the primary particles are evidenced by circles and ovals, whereas agglomerates are indicated by dotted lines with the specific color of each sample.

The specific surface area of the powders calcined at $950{ }^{\circ} \mathrm{C}$ for $5 \mathrm{~h}$ was lower than $5 \mathrm{~m}^{2} / \mathrm{g}$ for all the samples and cumulative pore volume at $\mathrm{P} / \mathrm{P}_{0}=0.99$ was about $0.02 \mathrm{~cm}^{3} / \mathrm{g}$. This is in agreement with previous studies on these perovskite-type compounds $[11,23,45,59]$.

\subsection{Redox Properties}

$\mathrm{H}_{2}$-TPR measurements were performed in the range $50-1050{ }^{\circ} \mathrm{C}$ to gain indications on the oxygen ions mobility and amount of oxygen released for each studied sample. $\mathrm{H}_{2}$-TPR are reactions of the sample at increasing temperatures in diluted hydrogen flow (reducing atmosphere) after an oxidative pretreatment that serves to remove any chemisorbed water, carbonate species or residual precursors which could interfere with the TCD signal. The pre-treated sample is then cooled down under inert atmosphere in order to remove any residual chemisorbed oxygen that by reacting with hydrogen could generate fictitious peaks. $\mathrm{H}_{2}$-TPR profiles indicate whether there is any oxygen bound to the sample and how strongly it is bound. The integration of the TPR peaks tells us how much hydrogen it took to reduce that oxygen, while the temperature of the peak indicates how much effort it took for hydrogen to tear it from the sample, and therefore how strongly it is bound. Therefore, it is possible to trace the oxidation states of the elements that have reducible species, i.e., iron and cobalt, whose oxidation state will gradually decrease from the initial value toward the metallic state. Figure $5 \mathrm{a}-\mathrm{d}$ report the $\mathrm{H}_{2}$-TPR 
curves as a function of temperature and the graphical fitting of the main peak in order to discriminate the various reduction contributions.
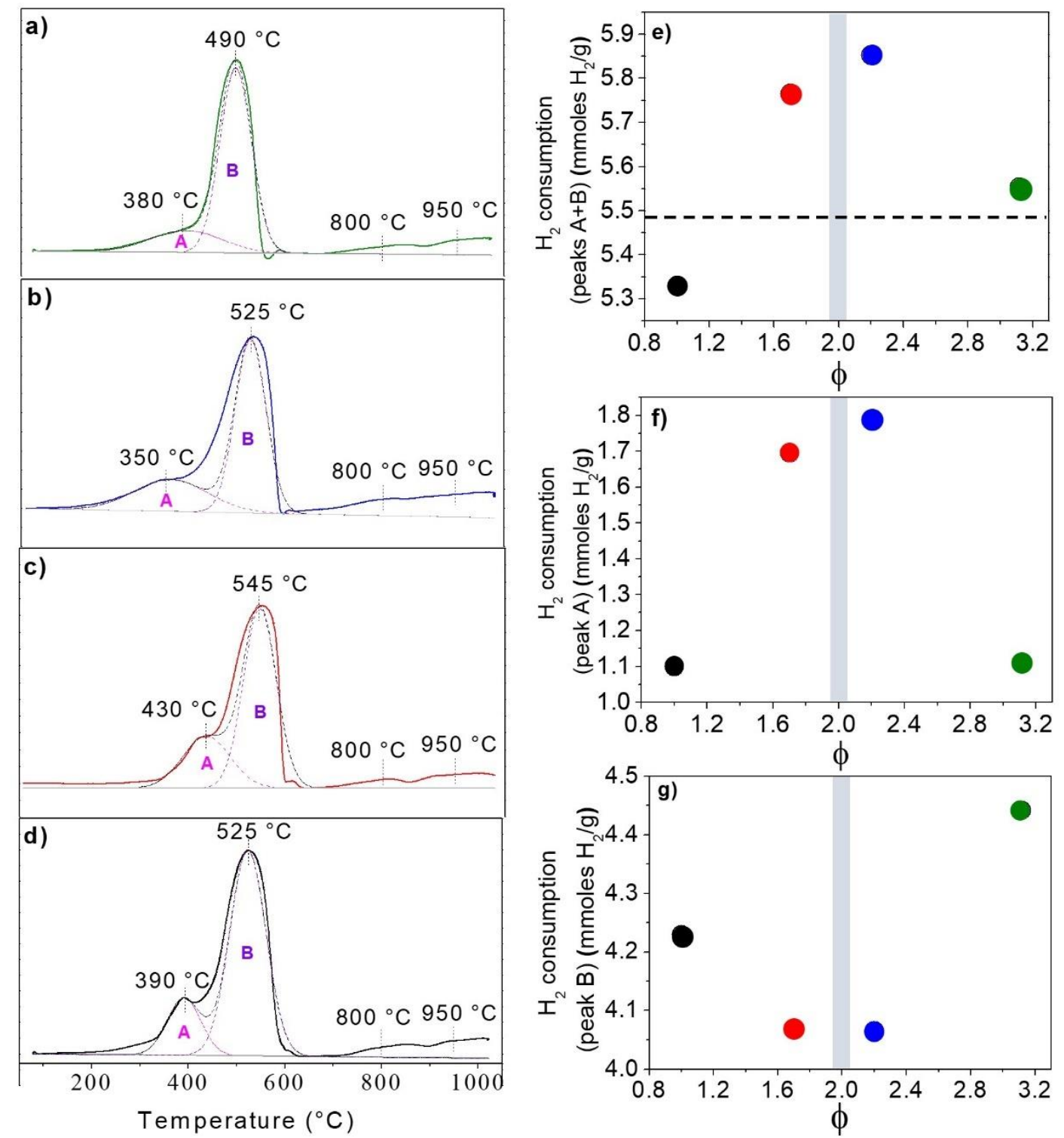

Figure 5. (a-d) $\mathrm{H}_{2}$-TPR profiles of the BSCF powders calcined at $950{ }^{\circ} \mathrm{C}$ for $5 \mathrm{~h}$ : (a) BSCF31 (green), (b) BSCF17 (red), (c) BSCF22 (blue) and (d) BSCF10 (black). (e-g) Volcano-type and other trends of $\mathrm{H}_{2}$-TPR parameters with $\Phi$.

As expected, the profile's shapes are very similar for all the samples (Figure 5a-d) and resemble the $\mathrm{H}_{2}$-TPR profiles reported in the literature for other iron and cobalt containing perovskite-type compounds [23,64]. In detail, there is a peak in the range $400-600{ }^{\circ} \mathrm{C}$ (peak B), with a shoulder in the range $200-400{ }^{\circ} \mathrm{C}$ (peak A), and further hydrogen consumption in the range $700-1000{ }^{\circ} \mathrm{C}$, which does not arrive at completeness. According to the literature, peaks $\mathrm{A}$ and $\mathrm{B}$ are mainly related to the reduction of cobalt species, whereas the smaller peaks at temperatures higher than $700{ }^{\circ} \mathrm{C}$ are related to the iron reduction $[23,64,65]$. Peak $\mathrm{A}$ is ascribable to the reduction of cobalt ions in high oxidation state, like $\mathrm{Co}^{4+}$ and $\mathrm{Fe}^{4+}\left(200-300{ }^{\circ} \mathrm{C}\right)$ and to the reduction of $\mathrm{Co}^{3+}$ in a surrounding which is different from the perovskite oxygens octahedra of the cubic structure $\left(300-450{ }^{\circ} \mathrm{C}\right)$ [23]. The hydrogen consumption related to the peak $\mathrm{A}$ is between 1.1 and $1.78 \mathrm{mmol} \mathrm{H}_{2} / \mathrm{g}$, whereas the overall consumption (peaks A + B) varies from 5.33 to $5.85 \mathrm{mmol} / \mathrm{g}$ (see also Figure $5 \mathrm{e}-\mathrm{g}$ ). Therefore, 
the reduction of some $\mathrm{Co}^{3+}$ to $\mathrm{Co}^{2+}$ species already occurred at low temperature (peak A), followed by the stepwise process $\mathrm{Co}^{3+}$ to $\mathrm{Co}^{2+}$ to $\mathrm{Co}^{0}$, which continues under peak $\mathrm{B}$. Indeed, postulating that, upon reduction of some $\mathrm{Co}^{4+}$ species (part of the peak A), all the cobalt species involved in peak $\mathrm{B}$ are $\mathrm{Co}^{3+}$, the theoretical hydrogen consumption required for the reduction of $\mathrm{Co}^{3+}$ to $\mathrm{Co}^{2+}$ to $\mathrm{Co}^{0}$ corresponds to $5.48 \mathrm{mmol} / \mathrm{g}$, and the overall consumption (peaks $\mathrm{A}+\mathrm{B}$ ) must be considered in order to account for the formation of $\mathrm{Co}^{0}$. The maximum temperatures of the peaks $\mathrm{A}$ and $\mathrm{B}$ are the lowest for BSC31 and BSCF22 and the highest for BSCF17 (Figure 5a-d). The low temperature of a reduction peak is usually associated with easily reducible species and/or to the presence of small grains. In particular, BSCF31 that exhibits the lowest reduction temperature for the peak B is the only sample with a single-phase, i.e., where $\mathrm{Co}^{3+}$ and $\mathrm{Co}^{2+}$ ions have the same chemical environment and thus are more easily reduced through a homogeneous process. The high grain agglomeration detected for BSCF17 and the presence of secondary phases account for the highest temperature of the maximum of peaks A and B for this sample (Figures 4 and 2d). Regarding iron reduction, $\mathrm{Fe}^{3+}$ and $\mathrm{Fe}^{2+}$ reduction to $\mathrm{Fe}^{0}$ starts above $700{ }^{\circ} \mathrm{C}$ and is completed only at temperatures above $1000{ }^{\circ} \mathrm{C}$. The XRD pattern of BSCF22 after TPR experiments is reported in Figure $\mathrm{S} 3$ as a representative pattern and demonstrates that the perovskite $\mathrm{ABO}_{3}$ structure has been totally destroyed by interaction with $\mathrm{H}_{2}$ up to $1000{ }^{\circ} \mathrm{C}$. In particular, cobalt is completely reduced to $\mathrm{Co}^{0}$, whereas iron remains in the $3+$ or $2+$ state (no metallic iron is present in the patterns), which is in agreement with the TPR results (Figure $5 b$ ).

The reduction parameters obtained from the analysis of the $\mathrm{H}_{2}$-TPR profiles have a nonlinear trend with $\Phi$, with a maximum or a minimum value at a $\Phi$ of about 2, as described in Figure 5e-g. Specifically, peaks A and B reported in Figure 5a-d correspond together to a hydrogen consumption in the range $5.35-5.85 \mathrm{mmol} \mathrm{H}_{2} / \mathrm{g}$, and its variation with $\Phi$ is reported in Figure 5e. The hydrogen consumption for peaks A + B is low for stoichiometric $\Phi$, increases up to BSCF22, and then decreases for BSCF31, drawing a volcano-type curve centered at about 2. Only BSCF31 and BSCF10 have a mean oxidation state for cobalt ions close to $3+$, since the theoretical amount of hydrogen necessary to reduce all the $\mathrm{Co}^{3+}$ is $5.48 \mathrm{mmol} \mathrm{H}_{2} / \mathrm{g}$. On the other hand, BSCF17 and BSCF22 contain a certain amount of $\mathrm{Co}^{4+}$ that increases the amount of consumed hydrogen (Figure 5e). Therefore, the lower hydrogen amount consumed for BSCF10 and BSCF31 is related with a lower amount of cobalt in high oxidation state with respect to BSCF17 and BSCF22. When examined separately, the hydrogen consumption of peak A and peak B (Figure $5 \mathrm{f}, \mathrm{g}$, respectively) have opposite trends with $\Phi$. The amount of Co ions which are reduced in peak $\mathrm{B}$ of BSCF31 is the highest one, since once $\mathrm{Co}^{4+}$ is reduced to $\mathrm{Co}^{3+}$ in peak $\mathrm{A}$, most of the $\mathrm{Co}^{3+}$ and $\mathrm{Co}^{2+}$ cations are reduced to metallic $\mathrm{Co}$ under peak $\mathrm{B}$. This indicates that all $\mathrm{Co}^{3+}$ and $\mathrm{Co}^{2+}$ cations have the same chemical environment, according to the single-phase nature of BSCF31 (Figure $5 \mathrm{~g}$ ). This is also in agreement with the lowest reduction temperature of peak B discussed above.

Considering that the amount of vacancies affects both adsorption of oxygen molecules and oxygen ions drifting along the electrode [4], TGA experiments were performed to evaluate the oxygen vacancies content in the investigated BSCF samples. The weight loss percentages of BSCF powders as a function of the temperature after oxidative pre-treatment according to steps 4 and 5 (see Section 4.2.3) are displayed in Figure 6. All BSCF samples exhibit an oxygen desorption behavior above $600{ }^{\circ} \mathrm{C}$, indicating a diversified presence of $\beta$-oxygen species typically observed for perovskite-type oxides (Figure 6). According to the literature, suprafacial or so called " $\alpha$-species" are generally released between $\sim 200-600^{\circ} \mathrm{C}$, depending on sample composition and surface oxygen vacancy content, while $\beta$-species desorb above $600^{\circ} \mathrm{C}$ and are due to "interfacial or bulk" oxygen species associated with the reducible ions present in the perovskite-type oxide [66-68]. None of the samples are able to retain suprafacial oxygen species during the $\mathrm{O}_{2}$ saturation step of the TGA (step 4), because no " $\alpha$-species" are released. This in in agreement with the very low specific surface area (lower than $5 \mathrm{~m}^{2} / \mathrm{g}$ ) of the BSCF samples calcined at $950{ }^{\circ} \mathrm{C}$ for $4 \mathrm{~h}$. The slight weight increase between 300 and $600{ }^{\circ} \mathrm{C}$ is ascribed to the oxidation of the $\mathrm{Co}^{3+}$ to $\mathrm{Co}^{4+}$ by the residual oxygen still present in the instrument chamber after steps $4-5$ carried out in the range $150-25^{\circ} \mathrm{C}$. Major differences (1 wt.\%) are observed in the content of "interfacial or bulk" oxygen species (Figure 6). 


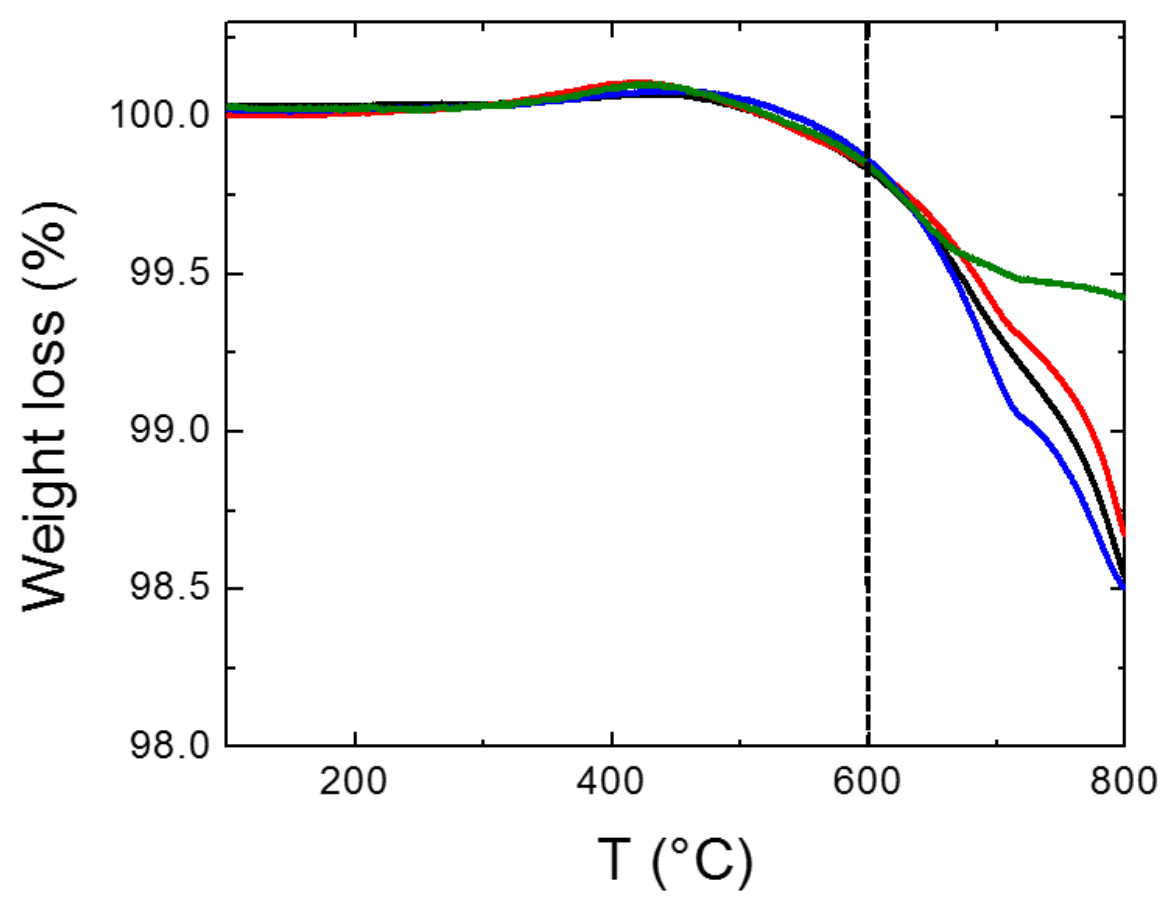

Figure 6. TGA curves measured under nitrogen after steps 4 and 5 (see experimental part, Section 2.2) for BSCF10 (black), BSCF17 (red), BSCF22 (blue) and BSCF31 (green).

In particular, BSCF31 releases less oxygen than the other three samples, and the total weight loss at $800{ }^{\circ} \mathrm{C}$ calculated from TGA experiments was $1 \%$ lower for BSCF31 than for the other three samples prepared using lower $\Phi$ ratios (Figure 6). Overall, it seems that the BSCF samples containing the secondary phase (BSCF10, BSCF17 and BSCF22) - where part of the cobalt is in less stable surroundings (see TPR experiments) and is thus more reducible-releases more $\beta$ oxygen above $600{ }^{\circ} \mathrm{C}$ (Figure 6 ). Conversely, the single-phase compound, BSCF31, loses less oxygen than the other three samples. Among the samples with secondary phase, another important factor that may affect the amount of $\beta$ oxygen released above $600{ }^{\circ} \mathrm{C}$ is the mean grain size: BSCF22 with very small grains shows the highest weight loss, followed by BSCF10, with moderate grain agglomeration and, finally, by BSCF17, the powder with the highest grain agglomeration (Figure 4).

\subsection{Electrocatalytic Activity}

To assess the electrochemical activity of prepared powders to be used as oxygen electrode, preliminary measurements were carried out on SDC/BSCF half cells at open circuit voltage. Activity and performance of the electrodes are strictly related to the starting powder, whose morphology plays a relevant role for an easy electrode deposition. The presence of agglomerates in BSCF 10, 17 and 22 actually prevented obtaining slurries that were suitable for adhering to the electrolyte surface, resulting in the detachment of the electrode layer during the sintering step. On the other hand, the absence of agglomerates in BSCF31 resulted in a smooth deposition of the powder, allowing the electrochemical testing of this sample. Figure 7 reports the Arrhenius plot of inverse polarization resistance $\left(R_{p}\right)$ of BSCF31 cathode, sintered at $1100{ }^{\circ} \mathrm{C}$ for $2 \mathrm{~h}$ on the SDC electrolyte. 


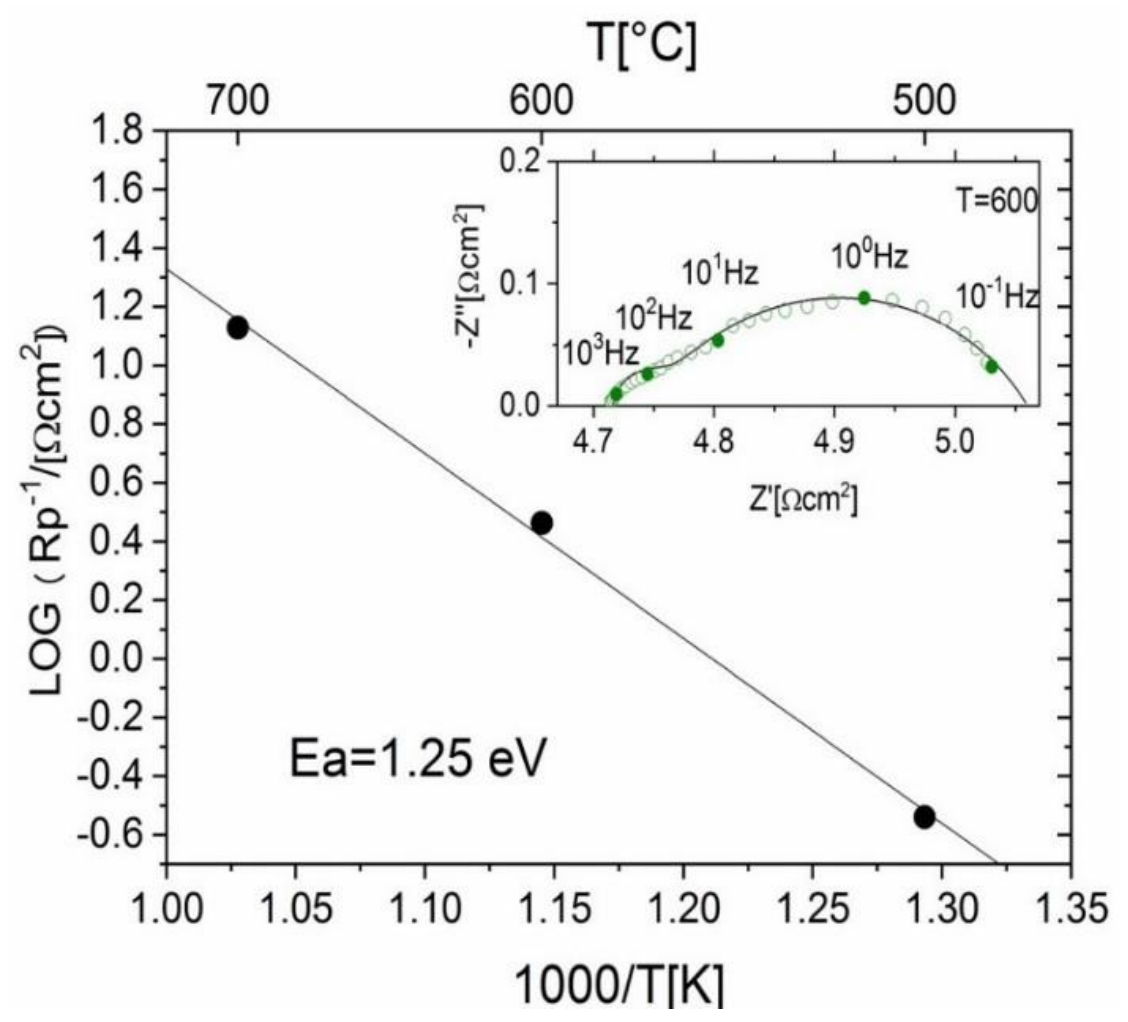

Figure 7. Arrhenius plot of inverse polarization resistance $\left(R_{p}\right)$ for the BSCF31/SDC system under air, measured in a three-electrode configuration (with a RE). The inset shows the Nyquist plot of impedance at $600{ }^{\circ} \mathrm{C}$.

The trend shows a good linearity in the explored temperature range $500-700{ }^{\circ} \mathrm{C}$ and a value of $120.5 \mathrm{~kJ} / \mathrm{mol}(1.25 \mathrm{eV})$ for the apparent activation energy of the $\mathrm{O}_{2}+2 \mathrm{e}^{-}=\mathrm{O}^{2-}$ redox reaction was extracted. The electrochemical results obtained for BSCF31 are in reasonable agreement with other studies $[23,69,70]$. The activation energy value is lower than in the literature, where a value between 127 and $131 \mathrm{~kJ} / \mathrm{mol}$ was calculated [71]. Any difference could be due to the different synthesis adopted or experimental conditions used. For example, Hieu et al. [72] found a very low activation energy for BSCF prepared by electrospinning and calcined at $950{ }^{\circ} \mathrm{C}$. On the other hand, the activation energy value obtained in this work is higher than those found in previous investigation on very similar BSCF electrodes [23], possibly due to non-optimized microstructures and/or interfacing with the supporting electrolyte. The electrode area specific resistance is $0.33 \mathrm{ohm} \mathrm{cm}{ }^{2}$ at $600{ }^{\circ} \mathrm{C}$. Although this value appears larger than that obtained for the same system in similar conditions [73], it is worth noting that the system performance can be fully improved through an optimization of the electrode architecture, being that beyond the scope of this study. A detailed analysis of the electrochemical behavior of BSCF31 is found in other publications of the authors [19,74]. In one of these works, BSCF31 was studied in comparison with a Lanthanum Strontium Cobalt Ferrite (LSCF), with and without infiltration of lanthanum strontium manganite [19]. In the other work, a detailed dynamic relaxation study was applied and compared with the conventional electrochemical analysis [74].

\section{Discussion}

The results showed that reducers-to-oxidizers ratio $(\Phi)$ has an evident effect on the combustion process, phase purity, structure, microstructure, morphology and reduction properties of the BSCF powders prepared by SCS. The effect of $\Phi$ is multiple and concerns, directly or indirectly, several powder features, as summarized in Figure 8. In particular, $\Phi$ has a direct effect on both the intensity of the combustion process and its redox environment. These two factors further influence structural, 
microstructural and redox properties of BSCF powders, which in turn have an effect on the adhesion of the powder onto the electrolyte and on the electrochemical properties (Figure 8).

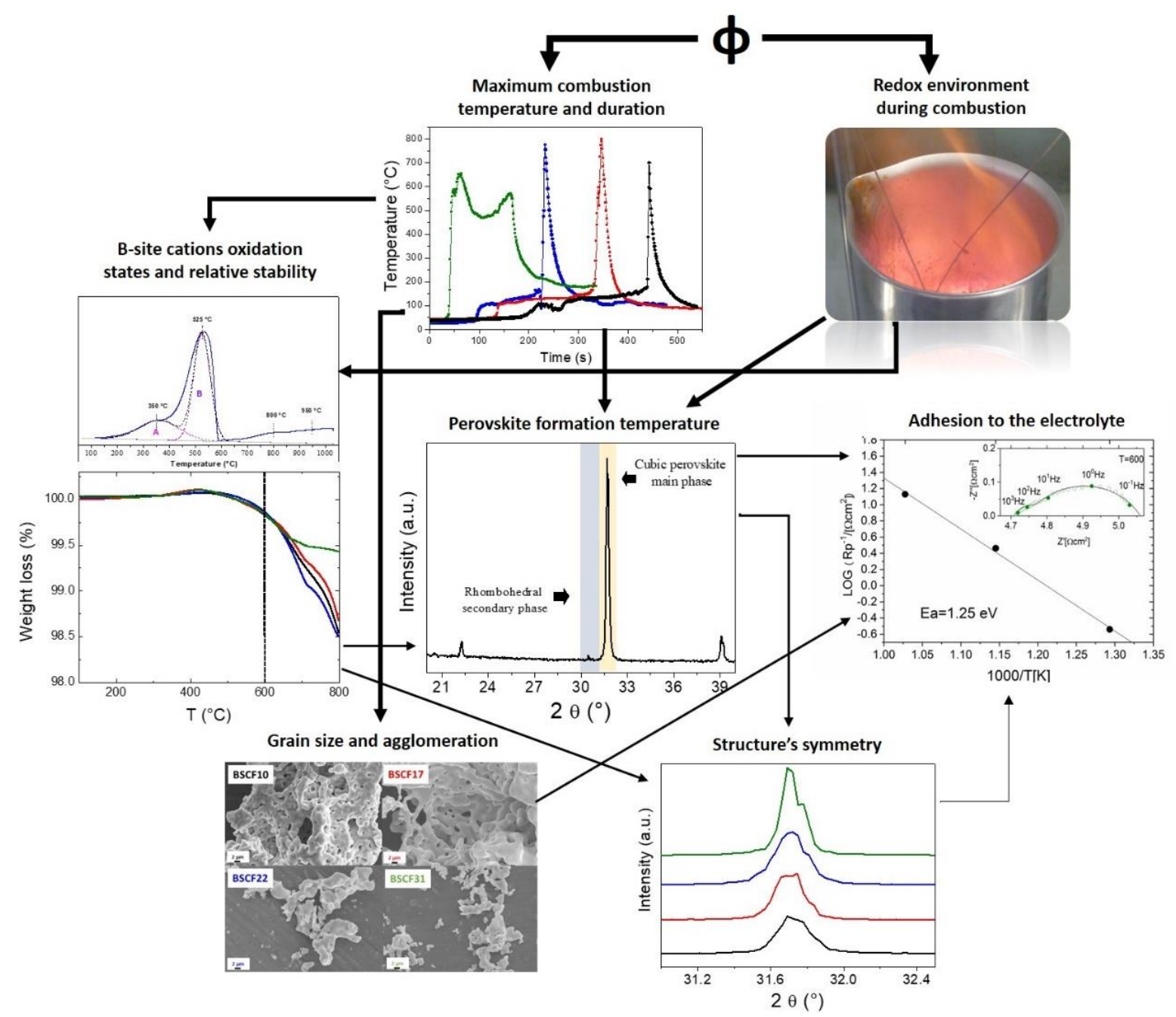

Figure 8. A summary of the multiple roles of the reducers-to-oxidizers ratio, $\Phi$, on the BSCF properties as electrode material. The cause-effect relationships are indicated by arrows of progressively smaller thickness in order to evidence primary, secondary, tertiary and further connections between $\Phi$ and BSCF properties.

The influence of temperature and redox environment during combustion on the BSCF material properties can be opposite and variable with $\Phi$, leading to both linear and nonlinear trends of the material properties with $\Phi$. The connections between the powder properties and their mutual effects are indicated in Figure 8 by the arrows. The variation of BSCF powder properties with $\Phi$ was linear for the structural properties (Figure 2d), suggesting a direct control of this parameter in the temperature of perovskite formation, whereas nonlinear trends, with a maximum or a minimum value at a $\Phi$ value of about 2, were observed for all the other properties (Figure 1c, Figure 5).

The cobalt oxidation state in BSCF and the combustion intensity affect the amount of secondary phase segregation, which increases linearly with $\Phi$ (Figure 8 ). This linear trend is the result of the contrasting trend with $\Phi$ of three different parameters that affect secondary phase formation. In BSCF10, the amount of cobalt species with high mean oxidation state is low (despite the low reducing environment), because the temperature of the combustion process is also relatively low (with respect to BSCF17 and BSCF22) and the low duration of the combustion temperature hinders the stabilization of a pure cubic structure, leaving un-burned nitrates after combustion (Figure 1d). In BSCF17 and BSCF22, 
the mean oxidation state of cobalt ions is higher than in the other samples (Figure 5e), but higher duration of the process gradually favors the formation of the cubic phase through the $\delta$-type $\mathrm{Ba} / \mathrm{Sr}$ mixed carbonate intermediates (Figure 1d). The combination of high reducing environment in the combustion process and long process duration, like in BSCF31, stabilizes the cubic phase with a lower mean oxidation state and hinders the secondary phase formation. In fact, secondary phase formation in BSCF powders is usually favored by the presence of oxygen and high mean oxidation state of cobalt ions, as indicated in the literature by the oxygen adsorption usually observed in the BSCF phase after thermal treatment at below $840{ }^{\circ} \mathrm{C}[20,75]$. Of course, secondary phase formation also depends on the BSCF cubic phase stability $[61,76]$. A poor interaction among the combustion mixture components or a decrease in the combustion process intensity may also affect the secondary phase formation [39].

Looking at the BSCF redox properties, despite the increasing reductive combustion environment from $\Phi=1$ (stoichiometric environment) to $\Phi=1.7$ (slightly reducing environment), the formation of cobalt ions with higher oxidation state, such as $\mathrm{Co}^{4+}$, is favored, due to the increase of maximum temperature in the combustion process (Figure 1b,c). For higher $\Phi$ values, from BSCF17 to BSCF22 and BSCF31, the increasing reducing environment of the fuel mixture gradually de-stabilizes $\mathrm{Co}^{4+}$ and produces a pure perovskite phase with relatively high content of species with a lower oxidation state $\left(\mathrm{Co}^{3+}\right.$ and $\left.\mathrm{Co}^{2+}\right)$. In a previous paper, Deganello et al. [23] found that the cobalt oxidation state in BSCF prepared by SCS was directly affected by the type of fuel (in particular by its reducing power) and by the fuel-to-metal cations ratio. In that paper, $\mathrm{Co}^{2+}$, present in the BSCF together with $\mathrm{Co}^{3+}$, was highly stabilized when sucrose-PEG 20,000 fuel mixtures were used, because these fuel mixtures showed high interaction with the metal cations and favored a reducing environment around the B-site cations of the BSCF perovskite. In this work, it is further clarified that the amount and stability of reducible species depend on the combustion process intensity and combustion redox environment, both controlled directly by the reducers-to-oxidizers ratio.

The scarce electrode-electrolyte adhesion observed by BSCF10, BSCF17 and BSCF22 is probably connected with the unfavorable powder microstructure of these BSCF samples. In fact, both the deposition procedure and the microstructure play an important role in the electrode adhesion [77]. For example, relatively small crystallites size and mixed grain size distribution are very important for the densification behavior [78]. In this sense, BSCF31, without large-sized agglomerates and a wide grain size distribution (Figure 4), appears to be suitable for a better adhesion to the SDC electrolyte. The effect of microstructure has also been discussed in the literature for BSCF powders prepared by electrospinning [77]. Looking at Figure 3b, another reasonable hypothesis is that the secondary phase, detected in the starting BSCF powders calcined at $950{ }^{\circ} \mathrm{C}$, introduced some distortion to the cubic symmetry of BSCF upon the thermal treatment at $1100^{\circ} \mathrm{C}$, that might negatively affect the cohesion between electrode and electrolyte.

Overall, it is possible to confirm that, as in the case of BSCF31, non-aggregated particles with a wide grain size distribution, associated with the absence of secondary phases resulted in optimal condition for the assembling in electrolyte-supported half-cell. From these considerations, it is evident that oxygen ion conduction in BSCF, which should be favored by high concentration and stability of cobalt species with lower mean oxidation state, is not the unique requirement for a successful application of a BSCF powder as oxygen electrocatalysts.

\section{Materials and Methods}

\subsection{Powders Preparation}

All the BSCF powders investigated in this work were prepared by solution combustion synthesis, starting from a sucrose-polyethylene glycol (Eridania, Italia S.P.A, Bologna, Italy -PEG, MW 20,000 purum, Fluka Chemie, Buchs, Switzerland and PEG MW 1000 Alfa Aesar GmbH \& Co KG, Kalsruhe, Germany) fuel mixture, as described in detail in a previous paper [23]. The PEG-to-sucrose and the sucrose-to-metal cations ratio were fixed at 1 and 2, respectively, whereas 
different reducers-to-oxidizers $(\Phi)$ ratio were explored in this work. The $\Phi$ was changed by adding an increasing amount of $\mathrm{NH}_{4} \mathrm{NO}_{3}$ to the same fuel and metal cations amount, as described in Figure 9.

\begin{tabular}{|c|c|c|c|}
\hline Sample name & Fuel mixture & $\phi$ & $\mathrm{g} \mathrm{NH}_{4} \mathrm{NO}_{3}$ \\
\hline BSCF10 & & 1.0 & 116 \\
\hline BSCF17 & & 1.7 & 63 \\
\hline BSCF22 & & 2.2 & 46 \\
\hline BSCF31 & 1: 1 molar ratio & 3.1 & 29 \\
\hline
\end{tabular}

Figure 9. Sample names, type of fuel mixture, corresponding $\Phi$ values and mass (grams) of ammonium nitrate used as additional oxidant to regulate the $\Phi$ ratio for the synthesis of $3 \mathrm{~g}$ of perovskite powder. Other synthesis conditions were maintained constant $\left(\mathrm{m}_{\text {sucrose }}=18.774 \mathrm{~g}, \mathrm{~m}_{\text {PEG } 20000}=2.416 \mathrm{~g}\right.$, $\left.\mathrm{m}_{\mathrm{Ba}(\mathrm{NO}) 2}=1.792 \mathrm{~g} ; \mathrm{m}_{\mathrm{Sr}(\mathrm{NO} 3) 2}=1.451 \mathrm{~g}, \mathrm{~m}_{\mathrm{Co}(\mathrm{NO} 3) 2 \cdot 6 \mathrm{H} 2 \mathrm{O}}=3.192 \mathrm{~g}, \mathrm{~m}_{\mathrm{Fe}(\mathrm{NO} 3) 3.9 \mathrm{H} 2 \mathrm{O}}=1.108 \mathrm{~g}\right)$.

$\mathrm{NH}_{4} \mathrm{NO}_{3}$ is a well-known oxidant, which, according to propellant chemistry concepts, has an oxidizing power of -2 . For details on the definition of $\Phi$ please refer to the of the review by Deganello et al. [39]. $\mathrm{NH}_{4} \mathrm{NO}_{3}$ ( $\geq 99.5 \%$, BioXtra-Sigma-Aldrich Chemie GmbH, Schnelldorf, Germany) was added to the reaction mixture as oxidant additive for the regulation of $\Phi$ (Figure 9). In brief, $\mathrm{Ba}\left(\mathrm{NO}_{3}\right)_{2}(99.1 \%$, Sigma-Aldrich WWR International, Fontenay-sous-Bois, France) was first dissolved in water at $50{ }^{\circ} \mathrm{C}$ in a $1 \mathrm{~L}$ stainless steel beaker under magnetic stirring. Then $\operatorname{Sr}\left(\mathrm{NO}_{3}\right)_{2}(\geq 99.99 \%$ Sigma-Aldrich), $\mathrm{Co}\left(\mathrm{NO}_{3}\right)_{2} \cdot 6 \mathrm{H}_{2} \mathrm{O}$ (99.99\% Sigma-Aldrich \& Co Saint Louis, MO 63103, USA) and $\mathrm{Fe}\left(\mathrm{NO}_{3}\right)_{3} \cdot 9 \mathrm{H}_{2} \mathrm{O}(99.99 \%$ Sigma-Aldrich \& Co Saint Louis, MO 63103, USA) were intimately mixed within the barium nitrate solution, together with the fuel and the $\Phi$ regulator and stirred at $80^{\circ} \mathrm{C}$ on a hot plate. When a peach-colored foam appeared on the surface of the sol, half of the sol was transferred in another $1 \mathrm{~L}$ stainless steel beaker for safety reasons. The self-sustaining combustion was subsequently initiated in each beaker by setting the hot-plate temperature at $350^{\circ} \mathrm{C}$ ( $\mathrm{T}$ in the stainless steel beaker was $210^{\circ} \mathrm{C}$ ). After combustion, a black powder was formed. The as-burned powders were then fired in stagnant air at $950{ }^{\circ} \mathrm{C}$ for $5 \mathrm{~h}$. For characterization purposes, a portion of the calcined powders was further treated at $1100{ }^{\circ} \mathrm{C}$ for $2 \mathrm{~h}$ under the same conditions used for cathode powder deposition onto the electrolyte.

\subsection{Powder Characterization}

\subsubsection{Temperature/Time Profiles}

To register temperature/time profiles, after the formation of the gel, the combustion vial was equipped with a type $\mathrm{K}$ thermocouple (diameter $=1.5 \mathrm{~mm}$; temperature range covered $=\mathrm{RT}-1100{ }^{\circ} \mathrm{C}$ ) connected to a computer through a data logger USB TC08 with 20 bit/s resolution (P.C.B. Technologies, 
60044 Fabriano, Ancona, Italy) with a dedicated software (PICO technology Ltd., Picolog version 5.20.3, DIO25-41, Copyright (C) 2020-2009). The thermocouple was set in the center of each $1 \mathrm{~L}$ combustion vial and the temperature was registered from the time the hotplate was on until the end of the combustion process.

\subsubsection{X-ray Powder Diffraction}

X-ray diffraction (XRD) measurements were collected with a Bruker-Siemens D5000 X-ray powder diffractometer (Bruker AXS, GmbH, Karlsruhe, Germany) equipped with a Kristalloflex 760 X-ray generator and a curved graphite monochromator on the diffracted beam. All the powders were carefully grinded by mortar and pestle before the XRD experiment. The observed range 10-135 $2 \theta$ was scanned with a step size of $0.03^{\circ} 2 \theta$ and an integration time of 20 s per step. Rietveld refinement of the diffraction patterns was carried out by using EXPGUI Software (revision 1.80, readexp.tcl, v 1.46, 13 September 2005) from the GSAS package [79] and the reliability factors ("R values") were generally acceptable. Chebyshev polynomials (15 variables) and Pearson type VII (Pseudo-Voigt with the Finger-Cox-Jephcoat asymmetry correction) functions were chosen for the background and for the peak profile fitting, respectively. In the structure refinement cell parameters, atomic coordinates, temperature displacements, scale factors, full width at half maximum (FWHM) and microstrain parameters were considered as variables. Phase identification was performed by using International Centre for Diffraction Data (ICDD) database (PDF-4+ 2020, Version 4.2001, DDV:4.20.0.1, ()2019 ICDD, Newtown Square, PA 19073-3273, USA). As a starting model for Rietveld Refinement of the $\mathrm{Ba}_{0.5} \mathrm{Sr}_{0.5} \mathrm{Co}_{0.8} \mathrm{Fe}_{0.2} \mathrm{O}_{3-\delta}$ perovskite phase a cubic $\mathrm{Pm}-3 \mathrm{~m}$ structure from ICDD database was chosen (PDF n 00-055-0563). For the secondary phase, a Ba, Sr and Co-containing P $63 \mathrm{~m}$ c structure was used as a starting model $\left(\mathrm{Ba}_{4.01} \mathrm{Sr}_{3.99} \mathrm{Co}_{4} \mathrm{O}_{15}\right.$, ICSD n $\left.{ }^{\circ} 290489\right)$.

\subsubsection{Thermogravimetric Analysis}

Thermogravimetric analyses (TGA) were performed with a TGA/DSC1 STAR system Mettler Toledo (Mettler Toledo, Bristol, United Kingdom). The sample $(15 \mathrm{mg})$ was pretreated in $\mathrm{N}_{2}(30 \mathrm{~mL} / \mathrm{min})$ heating from 25 to $500{ }^{\circ} \mathrm{C}\left(\mathrm{ramp}\right.$ rate $10^{\circ} \mathrm{C} / \mathrm{min}$ ) (step 1), holding time at $500{ }^{\circ} \mathrm{C}$ for $15 \mathrm{~min}$ (step 2), then, it was cooled down under nitrogen atmosphere to $150^{\circ} \mathrm{C}$ (step 3). Steps 1 and 2 were performed in order to remove any adsorbed water, oxygen or carbonate species. In step 3, the sample was filled with pure $\mathrm{O}_{2}(30 \mathrm{~mL} / \mathrm{min})$ at $150{ }^{\circ} \mathrm{C}$ during $1 \mathrm{~h}$ (step 4) and cooled to $25{ }^{\circ} \mathrm{C}$ still under $\mathrm{O}_{2}$ (step 5), in order to fill the oxygen vacancies. Finally, the sample was heated under $\mathrm{N}_{2}(30 \mathrm{~mL} / \mathrm{min})$ from room temperature up to $800{ }^{\circ} \mathrm{C}$ (ramp rate $5{ }^{\circ} \mathrm{C} / \mathrm{min}$ ) (step 6). During this last step, the removal of any chemisorbed oxygen species occurred and the weight loss between $\sim 200-600^{\circ} \mathrm{C}$ was taken into account in order to evaluate, if present, the surface oxygen vacancies content of the sample. The weight loss above $600{ }^{\circ} \mathrm{C}$ corresponds to the amount of bulk oxygen released.

\subsubsection{Temperature Programmed Reductions}

Reduction properties of the oxides were studied by temperature programmed reduction (TPR) measurements in $\mathrm{H}_{2} / \mathrm{Ar}(5 \%, 30 \mathrm{~mL} / \mathrm{min})$ in the range between room temperature and $1050^{\circ} \mathrm{C}$ (heating rate $10{ }^{\circ} \mathrm{C} / \mathrm{min}$ ). Experiments were carried out with a Micromeritics Autochem 2910 instrument equipped with a thermal conductivity detector (TCD) (Micromeritics Instrument Corp., Norcross, GA, USA) for the evaluation of hydrogen consumption with proper calibration curves. The accuracy of hydrogen consumption evaluated through TPR measurements is $\pm 10 \%$ and the temperature of peaks is quoted with an uncertainty of $\pm 15^{\circ} \mathrm{C}$. For each sample, about $0.1 \mathrm{~g}$ of powder previously calcined at $950{ }^{\circ} \mathrm{C}$ for $5 \mathrm{~h}$ was pre-treated in $\mathrm{O}_{2} / \mathrm{He}(5 \%, 50 \mathrm{~mL} / \mathrm{min})$ at $500{ }^{\circ} \mathrm{C}$ for $1 \mathrm{~h}$ and then cooled down under He atmosphere. 


\subsection{5. $\mathrm{N}_{2}$ Adsorption Measurements}

Specific surface area (by BET method) and cumulative pore volume at the saturation pressure $\left(\mathrm{P} / \mathrm{P}_{0}=0.99\right)$ were evaluated performing nitrogen adsorption/desorption measurements at $-196{ }^{\circ} \mathrm{C}$, using a Sorptomatic 1900 equipment (Thermoquest Italia S.p.a., Milano, Italy). All the samples were pre-treated under vacuum at $250{ }^{\circ} \mathrm{C}$ for $2 \mathrm{~h}$ prior to the measurements.

\subsubsection{Scanning Electron Microscopy}

A SEM EVO40 microscope operating at an emission voltage of $20 \mathrm{keV}$ was employed for the examination of the electrocatalytic powders microstructures.

\subsection{Half-Cell Preparation}

Electrolyte-supported half-cells were prepared, starting from $\mathrm{Ce}_{0.8} \mathrm{Sm}_{0.2} \mathrm{O}_{2-\delta}$ powder (SDC20-HP, Fuel Cell Materials), due to its high conductivity at intermediate temperature [80]. An amount of $6.5 \mathrm{~g}$ of powder was weighted for each electrolyte support and cold pressed at $60 \mathrm{MPa}$. After sintering at $1500^{\circ} \mathrm{C}$ for $5 \mathrm{~h}$ in air, the obtained SDC disks had a diameter of $25 \mathrm{~mm}$ and a thickness of $1.2 \mathrm{~mm}$. The electrodes were prepared as in the following: the BSCF powder was mixed with alpha-terpineol (natural, >96\%, FCC, FG, Ref: (-)-a-Terpineol, CAS 10482-56-1, Lot 09328PE, Item W304522, Sigma-Aldrich, Merck KGaA, Darmstadt, Germany) and manually grinded in a mortar, to form a paste suitable to be slurry-coated on the SDC surfaces, in order to form two symmetrical electrodes, acting as the working and the counter electrode (WE and CE, respectively). A circular electrode ( $1 \mathrm{~mm}$ wide) of the same BSCF mixture was deposited around the WE, at a distance equal to three-times the electrolyte thickness, to be used as reference electrode (RE) in the three-electrode configuration measurements, as shown in Scheme 1.

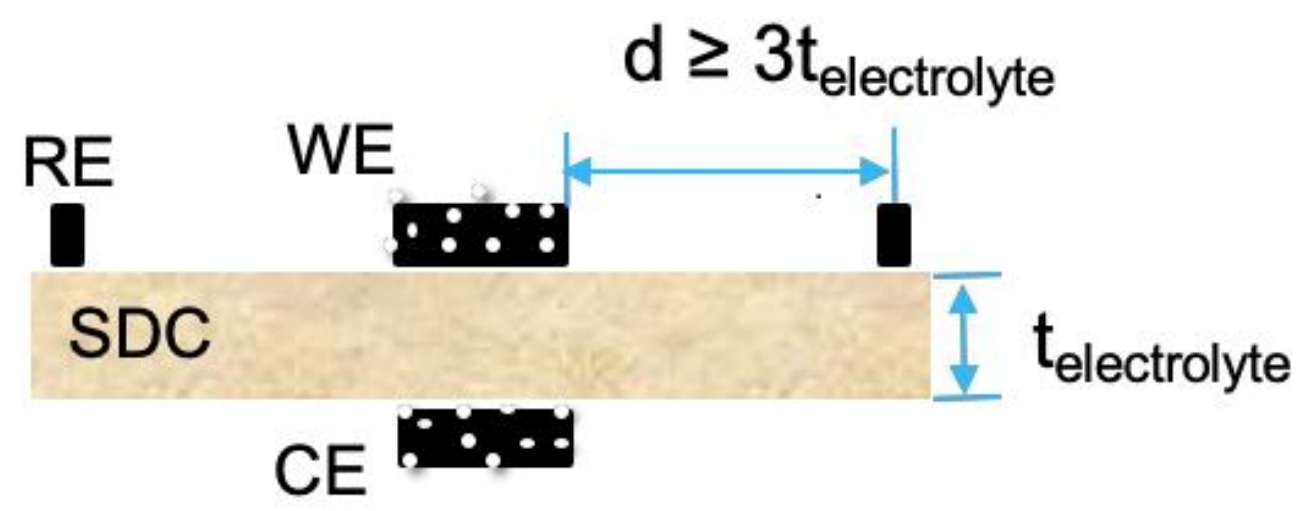

Scheme 1. Pictorial description of the three-electrode set up used for the electrochemical impedance measurements.

After sintering at $1100{ }^{\circ} \mathrm{C}$ for $2 \mathrm{~h}$, the observed WE and CE thickness was $20 \mu \mathrm{m}$, while their apparent geometric area was $0.28 \mathrm{~cm}^{2}$. Before the deposition of the BSCF mixture, the surfaces of the electrolytes were scraped ( $\mathrm{SiC}$ grinding paper, Grit 150) to improve the electrode adhesion. It is worth noting that the aforementioned deposition procedure was applied to all the four BSCF powders, although only with the BSCF31 specimen this procedure was effective in obtaining electrodes with a good adhesion to the electrolyte pellet. Therefore, the electrochemical investigation was carried out exclusively on the BSCF31-based half-cells.

\subsection{Electrochemical Characterization}

The electrochemical behavior of prepared half-cells was investigated through electrochemical impedance spectroscopy (EIS), placing the cell inside a home-designed test station, connected to a potentiostat coupled to a frequency response analyzer (Autolab PGSTAT302N, S.N. AUT83512, 
ECO CHEMIE BV, Utrecht, Netherlands). Impedance measurements were performed over the frequency range $10^{6}-10^{-1} \mathrm{~Hz}$ between 500 and $700^{\circ} \mathrm{C}$, at open circuit conditions. A Pt mesh was placed on both the $\mathrm{WE}$ and the $\mathrm{CE}$ as a current collector.

Inductance of the wires and cell rig was estimated during the EIS measurements and correction of the data have been performed according to Raikova et al. [81]. Equivalent circuit analysis (ZView software, Version 3.5f, Scribner Associates, Inc., Southern Pines, NC 28387, USA) was applied to obtain the physical parameters related to system electrochemical behavior.

\section{Conclusions}

This work evidenced that the choice of reducers-to-oxidizers ratios, $\Phi$, has important repercussions on the phase composition, structure, oxygen defectivity, microstructural-morphological features and reduction properties of the obtained $\mathrm{Ba}_{0.5} \mathrm{Sr}_{0.5} \mathrm{Co}_{0.8} \mathrm{Fe}_{0.2} \mathrm{O}_{3-\delta}$ electrode materials. An important consequence is that the use of a stoichiometric reducers-to-oxidizers ratio may be not always the best choice, depending on the chemical composition and application of the investigated materials. The $\Phi$ effect was not always linear in the over stoichiometric $\Phi$ range, reflecting its multiple role in the powder properties. The observed nonlinear trends of the reduction properties with the reducers-to-oxidizers ratio are in agreement with contrasting effects of (i) the reducing effect of higher $\Phi$ ratios, which affects cobalt reduction and stability of the cobalt species with lower mean oxidation state, (ii) the intensity of the combustion process, which regulates the amount and stability of cobalt species with higher mean oxidation state, and (iii) the duration of the combustion process, which influences the stability of the final cubic phase through the formation of $\mathrm{Ba} / \mathrm{Sr}$ mixed carbonates intermediates in the as-burned powders.

This work further confirmed that high oxygen ion conduction is not the unique factor affecting the electrochemical performance of this perovskite-type electrocatalysts. Phase purity of the starting BSCF powder and convenient microstructure and morphology also play a fundamental role in electrode-electrolyte adhesion. In fact, the highest $\Phi$ values are effective (i) in the suppression of secondary phase formation and promotion of the cubic symmetry, and (ii) in the establishment of favorable particle size distribution, despite the increasing in the average grain size.

Finally, our results highlighted that the selection of the best reducers-to-oxidizers ratio is a complex procedure and depends on several factors. All these factors need to be considered in the selection of $\Phi$ and their effect into the final materials performance further depends on the selected materials composition and application. Overall, the BSCF powder with the highest over stoichiometric $\Phi$ value gave the best results for application as electrode material, thanks to an optimal combination of its structural, redox, microstructural/morphological features, allowing an efficient deposition of the cathode powder onto the ceria-based electrolyte. These findings can be conveniently used for a better control of materials properties and performance of oxygen electrocatalysts.

Supplementary Materials: The following are available online at http://www.mdpi.com/2073-4344/10/12/1465/s1, Figure S1: trend on the cubic BSCF cell parameter with the amount of secondary phase in the calcined powders; Figure S2: TGA under airflow of BSCF17, BSCF22 and BSCF31 as-burned powders; Figure S3: XRD patterns of BSCF22 powders after $\mathrm{H} 2-\mathrm{TPR}$.

Author Contributions: Conceptualization, F.D., C.A. and M.P.C.; formal analysis, F.D., L.F.L., D.C. and S.P.; investigation, F.D., C.A., L.F.L., M.P.C., D.C. and S.P.; writing — original draft preparation, F.D.; writing - review and editing, C.A., L.F.L., A.B., M.V., M.P.C. and S.P. All authors have read and agreed to the published version of the manuscript.

Funding: This research received no external funding.

Acknowledgments: F. Deganello, C. Aliotta and L.F. Liotta are grateful to Francesco Giordano for performing the XRD measurements. L. F. Liotta has carried part of this research in the field of the COST Action 18224 "Green Chemical Engineering Network towards upscaling sustainable processes".

Conflicts of Interest: The authors declare no conflict of interest. 


\section{References}

1. Arul, N.S.; Nithya, V.D. (Eds.) Revolution of Perovskite; Materials Horizons: From Nature to Nanomaterials; Springer: Singapore, 2020; ISBN 978-981-15-1266-7.

2. Abdalla, A.M.; Hossain, S.; Azad, A.T.; Petra, P.M.I.; Begum, F.; Eriksson, S.G.; Azad, A.K. Nanomaterials for solid oxide fuel cells: A review. Renew. Sustain. Energy Rev. 2018, 82, 353-368. [CrossRef]

3. Zhou, W.; Ran, R.; Shao, Z. Progress in understanding and development of $\mathrm{Ba}_{0.5} \mathrm{Sr}_{0.5} \mathrm{Co}_{0.8} \mathrm{Fe}_{0.2} \mathrm{O}_{3-\delta}-$ based cathodes for intermediate-temperature solid-oxide fuel cells: A review. J. Power Sources 2009, 192, $231-246$. [CrossRef]

4. Adler, S.B. Factors governing oxygen reduction in solid oxide fuel cell cathodes. Chem. Rev. 2004, 104, 4791-4843. [CrossRef]

5. Yang, G.; Su, C.; Shi, H.; Zhu, Y.; Song, Y.; Zhou, W.; Shao, Z. Toward Reducing the Operation Temperature of Solid Oxide Fuel Cells: Our Past 15 Years of Efforts in Cathode Development. Energy Fuels 2020, in press. [CrossRef]

6. Mcintosh, S.; Vente, J.; Haije, W.; Blank, D.; Bouwmeester, H. Structure and oxygen stoichiometry of $\mathrm{SrCo}_{0.8} \mathrm{Fe}_{0.2} \mathrm{O}_{3-\delta}$ and $\mathrm{Ba}_{0.5} \mathrm{Sr}_{0.5} \mathrm{Co}_{0.8} \mathrm{Fe}_{0.2} \mathrm{O}_{3-\delta}$. Solid State Ionics 2006, 177, 1737-1742. [CrossRef]

7. Jun, A.; Kim, J.; Shin, J.; Kim, G. Perovskite as a Cathode Material: A Review of its Role in Solid-Oxide Fuel Cell Technology. ChemElectroChem 2016, 3, 511-530. [CrossRef]

8. Shao, Z. Investigation of the permeation behavior and stability of a $\mathrm{Ba}_{0.5} \mathrm{Sr}_{0.5} \mathrm{Co}_{0.8} \mathrm{Fe}_{0.2} \mathrm{O}_{3-\delta}$ oxygen membrane. J. Membr. Sci. 2000, 172, 177-188. [CrossRef]

9. Vente, J.F.; McIntosh, S.; Haije, W.G.; Bouwmeester, H.J.M. Properties and performance of $\mathrm{Ba}_{\mathrm{x}} \mathrm{Sr}_{1-\mathrm{x}} \mathrm{Co}_{0.8} \mathrm{Fe}_{0.2} \mathrm{O}_{3-\delta}$ materials for oxygen transport membranes. J. Solid State Electrochem. 2006, 10, 581-588. [CrossRef]

10. Shao, Z.; Haile, S.M. A high-performance cathode for the next generation of solid-oxide fuel cells. In Materials for Sustainable Energy; Macmillan Publishers Ltd. (Irading as Nature Publishing Group): London, UK; World Scientific Publishing Co. Pte. Ltd.: Singapore, 2010; Volume 3, pp. 255-258, ISBN 9789814317665.

11. Chen, F.; Xue, L.; Shang, Z.; Zhang, Z.; Chen, D. An enhanced non-noble perovskite-based oxygen electrocatalyst for efficient oxygen reduction and evolution reactions. J. Solid State Chem. 2020, 282, 121119. [CrossRef]

12. Dai, Y.; Yu, J.; Cheng, C.; Tan, P.; Ni, M. Mini-review of perovskite oxides as oxygen electrocatalysts for rechargeable zinc-air batteries. Chem. Eng. J. 2020, 397, 125516. [CrossRef]

13. Fabbri, E.; Nachtegaal, M.; Cheng, X.; Schmidt, T.J. Superior Bifunctional Electrocatalytic Activity of $\mathrm{Ba}_{0.5} \mathrm{Sr}_{0.5} \mathrm{Co}_{0.8} \mathrm{Fe}_{0.2} \mathrm{O}_{3-\delta} /$ Carbon Composite Electrodes: Insight into the Local Electronic Structure. Adv. Energy Mater. 2015, 5, 1402033. [CrossRef]

14. Carpanese, M.P.; Clematis, D.; Viviani, M.; Presto, S.; Cerisola, G.; Panizza, M.; Delucchi, M. A Comprehensive Approach to Improve Performance and Stability of State-of-the-Art Air Electrodes for Intermediate Temperature Reversible Cells: An Impedance Spectroscopy Analysis. Bulg. Chem. Commun. 2018, 50, 39-47.

15. Kannan, R.; Singh, K.; Gill, S.; Fürstenhaupt, T.; Thangadurai, V. Chemically Stable Proton Conducting Doped $\mathrm{BaCeO}_{3}-\mathrm{No}$ More Fear to SOFC Wastes. Sci. Rep. 2013, 3, 2138. [CrossRef] [PubMed]

16. Singh, K.; Kannan, R.; Thangadurai, V. Perspective of perovskite-type oxides for proton conducting solid oxide fuel cells. Solid State Ionics 2019, 339, 114951. [CrossRef]

17. Xu, X.; Wang, H.; Fronzi, M.; Wang, X.; Bi, L.; Traversa, E. Tailoring cations in a perovskite cathode for proton-conducting solid oxide fuel cells with high performance. J. Mater. Chem. A 2019, 7, 20624-20632. [CrossRef]

18. Müller, P.; Störmer, H.; Meffert, M.; Dieterle, L.; Niedrig, C.; Wagner, S.F.; Ivers-Tiffée, E.; Gerthsen, D. Secondary Phase Formation in $\mathrm{Ba}_{0.5} \mathrm{Sr}_{0.5} \mathrm{Co}_{0.8} \mathrm{Fe}_{0.2} \mathrm{O}_{3-\mathrm{d}}$ Studied by Electron Microscopy. Chem. Mater. 2013, 25, 564-573. [CrossRef]

19. Giuliano, A.; Carpanese, M.P.; Clematis, D.; Boaro, M.; Pappacena, A.; Deganello, F.; Liotta, L.F.; Barbucci, A. Infiltration, Overpotential and Ageing Effects on Cathodes for Solid Oxide Fuel Cells: $\mathrm{La}_{0.6} \mathrm{Sr}_{0.4} \mathrm{Co}_{0.2} \mathrm{Fe}_{0.8} \mathrm{O}_{3-\delta}$ versus $\mathrm{Ba}_{0.5} \mathrm{Sr}_{0.5} \mathrm{Co}_{0.8} \mathrm{Fe}_{0.2} \mathrm{O}_{3-\delta}$. J. Electrochem. Soc. 2017, 164, F3114-F3122. [CrossRef]

20. Wang, F.; Nakamura, T.; Yashiro, K.; Mizusaki, J.; Amezawa, K. The crystal structure, oxygen nonstoichiometry and chemical stability of $\mathrm{Ba}_{0.5} \mathrm{Sr}_{0.5} \mathrm{Co}_{0.8} \mathrm{Fe}_{0.2} \mathrm{O}_{3-\delta}$ (BSCF). Phys. Chem. Chem. Phys. 2014, 16, 7307. [CrossRef] 
21. Švarcová, S.; Wiik, K.; Tolchard, J.; Bouwmeester, H.J.M.; Grande, T. Structural instability of cubic perovskite $\mathrm{Ba}_{\mathrm{x}} \mathrm{Sr}_{1-\mathrm{x}} \mathrm{Co}_{1-\mathrm{y}} \mathrm{Fe}_{\mathrm{y}} \mathrm{O}_{3-\delta}$. Solid State Ionics 2008, 178, 1787-1791. [CrossRef]

22. Zeljkovic, S.; Ivas, T.; Vaucher, S.; Jelic, D.; Gauckler, L. The changes of $\mathrm{Ba}_{0.5} \mathrm{Sr}_{0.5} \mathrm{Co}_{0.8} \mathrm{Fe}_{0.2} \mathrm{O}_{3-\delta}$ perovskite oxide on heating in oxygen and carbon dioxide atmospheres. J. Serbian Chem. Soc. 2014, 79, 1141-1154. [CrossRef]

23. Deganello, F.; Liotta, L.F.; Marcì, G.; Fabbri, E.; Traversa, E. Strontium and iron-doped barium cobaltite prepared by solution combustion synthesis: Exploring a mixed-fuel approach for tailored intermediate temperature solid oxide fuel cell cathode materials. Mater. Renew. Sustain. Energy 2013, 2, 8. [CrossRef]

24. Zhao, Z.; Liu, L.; Zhang, X.; Tu, B.; Ou, D.; Cheng, M. Carbonates formed during BSCF preparation and their effects on performance of SOFCs with BSCF cathode. Int. J. Hydrog. Energy 2012, 37, 19036-19044. [CrossRef]

25. Unger, L.-S.; Ruhl, R.; Meffert, M.; Niedrig, C.; Menesklou, W.; Wagner, S.F.; Gerthsen, D.; Bouwmeester, H.J.M.; Ivers-Tiffée, E. Yttrium doping of $\mathrm{Ba}_{0.5} \mathrm{Sr}_{0.5} \mathrm{Co}_{0.8} \mathrm{Fe}_{0.2} \mathrm{O}_{3-\delta}$ part II: Influence on oxygen transport and phase stability. J. Eur. Ceram. Soc. 2018, 38, 2388-2395. [CrossRef]

26. Kim, J.; Choi, S.; Jun, A.; Jeong, H.Y.; Shin, J.; Kim, G. Chemically Stable Perovskites as Cathode Materials for Solid Oxide Fuel Cells: La-Doped $\mathrm{Ba}_{0.5} \mathrm{Sr}_{0.5} \mathrm{Co}_{0.8} \mathrm{Fe}_{0.2} \mathrm{O}_{3-\delta}$. ChemSusChem 2014, 7, 1669-1675. [CrossRef]

27. Abubaker, O.A.; Singh, K.; Thangadurai, V. Investigating the effect of $\mathrm{Cu}$-doping on the electrochemical properties of perovskite-type $\mathrm{Ba}_{0.5} \mathrm{Sr}_{0.5} \mathrm{Fe}_{1-\mathrm{x}} \mathrm{Cu}_{\mathrm{x}} \mathrm{O}_{3-\delta}(0 \leq \mathrm{x} \leq 0.20)$ cathodes. J. Power Sources 2020, 451, 227777. [CrossRef]

28. Clematis, D.; Barbucci, A.; Presto, S.; Viviani, M.; Carpanese, M.P. Electrocatalytic activity of perovskite-based cathodes for solid oxide fuel cells. Int. J. Hydrog. Energy 2019, 44, 6212-6222. [CrossRef]

29. Giuliano, A.; Carpanese, M.P.; Panizza, M.; Cerisola, G.; Clematis, D.; Barbucci, A. Characterisation of $\mathrm{La}_{0.6} \mathrm{Sr}_{0.4} \mathrm{Co}_{0.2} \mathrm{Fe}_{0.8} \mathrm{O}_{3-\delta}-\mathrm{Ba}_{0.5} \mathrm{Sr}_{0.5} \mathrm{Co}_{0.8} \mathrm{Fe}_{0.2} \mathrm{O}_{3-\delta}$ composite as cathode for solid oxide fuel cells. Electrochim. Acta 2017, 240, 258-266. [CrossRef]

30. Bertei, A.; Barbucci, A.; Carpanese, M.P.; Viviani, M.; Nicolella, C. Morphological and electrochemical modeling of SOFC composite cathodes with distributed porosity. Chem. Eng. J. 2012, 207-208, 167-174. [CrossRef]

31. Nicolella, C.; Bertei, A.; Viviani, M.; Barbucci, A. Morphology and electrochemical activity of SOFC composite cathodes: II. Mathematical modelling. J. Appl. Electrochem. 2009, 39, 503-511. [CrossRef]

32. Zeng, Q.; Zhang, X.; Wang, W.; Zhang, D.; Jiang, Y.; Zhou, X.; Lin, B. A Zn-Doped $\mathrm{Ba}_{0.5} \mathrm{Sr}_{0.5} \mathrm{Co}_{0.8} \mathrm{Fe}_{0.2} \mathrm{O}_{3-\delta}$ Perovskite Cathode with Enhanced ORR Catalytic Activity for SOFCs. Catalysts 2020, 10, 235. [CrossRef]

33. Zhu, X.; Xia, H.; Li, Y.; Lü, Z. A ( $\mathrm{La}, \mathrm{Sr}) \mathrm{MnO}_{3}$ nano-film embedded into $(\mathrm{Ba}, \mathrm{Sr})(\mathrm{Co}, \mathrm{Fe}) \mathrm{O}_{3}$ porous cathode for stability enhancement. Mater. Lett. 2015, 161, 549-553. [CrossRef]

34. Souza, D.F.; Nunes, E.H.M.; Vasconcelos, W.L. Preparation of $\mathrm{Ba}_{0.5} \mathrm{Sr}_{0.5} \mathrm{Co}_{0.8} \mathrm{Fe}_{0.2} \mathrm{O}_{3-\delta}$ asymmetric structures by freeze-casting and dip-coating. Ceram. Int. 2018, 44, 1002-1006. [CrossRef]

35. Choi, J.; Park, I.; Lee, H.; Shin, D. Effect of enhanced reaction area in double layered $\mathrm{Ba}_{0.5} \mathrm{Sr}_{0.5} \mathrm{Co}_{0.8} \mathrm{Fe}_{0.2} \mathrm{O}_{3-\delta}$ cathode for intermediate temperature solid oxide fuel cells. Solid State Ionics 2012, 216, 54-57. [CrossRef]

36. Habiballah, A.S.; Osman, N.; Md Jani, A.M. Microstructural investigation of BSCF-based cathode material for enhanced oxygen reduction reaction performance and electrode stability. Ceram. Int. 2020, 46, 23262-23265. [CrossRef]

37. Liu, J.; Bao, H.; Zhang, B.; Hua, Q.; Shang, M.; Wang, J.; Jiang, L. Geometric Occupancy and Oxidation State Requirements of Cations in Cobalt Oxides for Oxygen Reduction Reaction. ACS Appl. Mater. Interfaces 2019, 11, 12525-12534. [CrossRef] [PubMed]

38. Aegerter, D.; Borlaf, M.; Fabbri, E.; Clark, A.H.; Nachtegaal, M.; Graule, T.; Schmidt, T.J. Tuning the Co Oxidation State in $\mathrm{Ba}_{0.5} \mathrm{Sr}_{0.5} \mathrm{Co}_{0.8} \mathrm{Fe}_{0.2} \mathrm{O}_{3-\delta}$ by Flame Spray Synthesis Towards High Oxygen Evolution Reaction Activity. Catalysts 2020, 10, 984. [CrossRef]

39. Deganello, F.; Tyagi, A.K. Solution combustion synthesis, energy and environment: Best parameters for better materials. Prog. Cryst. Growth Charact. Mater. 2018, 64, 23-61. [CrossRef]

40. Varma, A.; Mukasyan, A.S.; Rogachev, A.S.; Manukyan, K.V. Solution Combustion Synthesis of Nanoscale Materials. Chem. Rev. 2016, 116, 14493-14586. [CrossRef]

41. Deganello, F. Nanomaterials for environmental and energy applications prepared by solution combustion based-methodologies: Role of the fuel. Mater. Today Proc. 2017, 4, 5507-5516. [CrossRef] 
42. Ashok, A.; Kumar, A.; Bhosale, R.R.; Almomani, F.; Saleh Saad, M.A.H.; Suslov, S.; Tarlochan, F. Influence of fuel ratio on the performance of combustion synthesized bifunctional cobalt oxide catalysts for fuel cell application. Int. J. Hydrog. Energy 2019, 44, 436-445. [CrossRef]

43. Kermani, F.; Mollazadeh, S.; Vahdati Khaki, J. A simple thermodynamics model for estimation and comparison the concentration of oxygen vacancies generated in oxide powders synthesized via the solution combustion method. Ceram. Int. 2019, 45, 13496-13501. [CrossRef]

44. Xu, X.; Pan, Y.; Zhou, W.; Chen, Y.; Zhang, Z.; Shao, Z. Toward Enhanced Oxygen Evolution on Perovskite Oxides Synthesized from Different Approaches: A Case Study of $\mathrm{Ba}_{0.5} \mathrm{Sr}_{0.5} \mathrm{Co}_{0.8} \mathrm{Fe}_{0.2} \mathrm{O}_{3-\delta}$. Electrochim. Acta 2016, 219, 553-559. [CrossRef]

45. Nuernberg, R.B.; Morelli, M.R. Synthesis of BSCF perovskites using a microwave-assisted combustion method. Ceram. Int. 2016, 42, 4204-4211. [CrossRef]

46. Ail, S.S.; Benedetti, V.; Baratieri, M.; Dasappa, S. Fuel-Rich Combustion Synthesized $\mathrm{Co} / \mathrm{Al}_{2} \mathrm{O}_{3}$ Catalysts for Wax and Liquid Fuel Production via Fischer-Tropsch Reaction. Ind. Eng. Chem. Res. 2018, 57, 3833-3843. [CrossRef]

47. Afshari, M.; Rouhani Isfahani, A.; Hasani, S.; Davar, F.; Jahanbani Ardakani, K. Effect of apple cider vinegar agent on the microstructure, phase evolution, and magnetic properties of $\mathrm{CoFe}_{2} \mathrm{O}_{4}$ magnetic nanoparticles. Int. J. Appl. Ceram. Technol. 2019, 16, 1612-1621. [CrossRef]

48. Abu-Zied, B.M. Controlled synthesis of praseodymium oxide nanoparticles obtained by combustion route: Effect of calcination temperature and fuel to oxidizer ratio. Appl. Surf. Sci. 2019, 471, 246-255. [CrossRef]

49. Ashok, A.; Kumar, A.; Bhosale, R.R.; Almomani, F.; Malik, S.S.; Suslov, S.; Tarlochan, F. Combustion synthesis of bifunctional $\mathrm{LaMO}_{3}(\mathrm{M}=\mathrm{Cr}, \mathrm{Mn}, \mathrm{Fe}, \mathrm{Co}, \mathrm{Ni})$ perovskites for oxygen reduction and oxygen evolution reaction in alkaline media. J. Electroanal. Chem. 2018, 809, 22-30. [CrossRef]

50. Shimna, T.; Thomas, J.; Joseph, T.; Thomas, T.; Thomas, N. Porosity tuned NiO nanocrystallites by solution combustion synthesis for the development of a voltammetric sensor for dopamine. J. Porous Mater. 2019, 26, 1455-1463. [CrossRef]

51. da Conceição, L.; Ribeiro, N.F.P.; Furtado, J.G.M.; Souza, M.M.V.M. Effect of propellant on the combustion synthesized Sr-doped $\mathrm{LaMnO}_{3}$ powders. Ceram. Int. 2009, 35, 1683-1687. [CrossRef]

52. Jamale, A.P.; Shanmugam, S.; Bhosale, C.H.; Jadhav, L.D. Physiochemical properties of combustion synthesized $\mathrm{La}_{0.6} \mathrm{Sr}_{0.4} \mathrm{Co}_{0.8} \mathrm{Fe}_{0.2} \mathrm{O}_{3-\delta}$ perovskite: A role of fuel to oxidant ratio. Mater. Sci. Semicond. Process. 2015, 40, 855-860. [CrossRef]

53. Aali, H.; Mollazadeh, S.; Khaki, J.V. Quantitative evaluation of ambient $\mathrm{O}_{2}$ interference during solution combustion synthesis process:considering iron nitrate-Fuel system. Ceram. Int. 2019, 45, 17775-17783. [CrossRef]

54. Xu, C.; Manukyan, K.V.; Adams, R.A.; Pol, V.G.; Chen, P.; Varma, A. One-step solution combustion synthesis of $\mathrm{CuO} / \mathrm{Cu} 2 \mathrm{O} / \mathrm{C}$ anode for long cycle life Li-ion batteries. Carbon N. Y. 2019, 142, 51-59. [CrossRef]

55. Singh, G.; Tiwari, V.S.; Tiwari, P.; Srivastava, A.K.; Gupta, P.K. Effect of oxidant-to-fuel ratios on phase formation of PLZT powder; prepared by gel-combustion. J. Alloys Compd. 2011, 509, 4127-4131. [CrossRef]

56. Ehi-Eromosele, C.O.; Ita, B.I.; Iweala, E.E.J.; Ogunniran, K.O.; Adekoya, J.A.; Ehi-Eromosele, F.E. Structural and magnetic characterization of $\mathrm{La}_{0.7} \mathrm{Sr}_{0.3} \mathrm{MnO}_{3}$ nanoparticles obtained by the citrate-gel combustion method: Effect of fuel to oxidizer ratio. Ceram. Int. 2016, 42, 636-643. [CrossRef]

57. Liu, B.; Zhang, Y. $\mathrm{Ba}_{0.5} \mathrm{Sr}_{0.5} \mathrm{Co}_{0.8} \mathrm{Fe}_{0.2} \mathrm{O}_{3}$ nanopowders prepared by glycine-nitrate process for solid oxide fuel cell cathode. J. Alloys Compd. 2008, 453, 418-422. [CrossRef]

58. Mukasyan, A.S.; Dinka, P. Novel approaches to solution-combustion synthesis of nanomaterials. Int. J. Self Propag. High Temp. Synth. 2007, 16, 23-35. [CrossRef]

59. Yusoff, F.; Aziz, A.; Mohamed, N.; Ab Ghani, S. Synthesis and characterizations of BSCF at different ph as future cathode materials for fuel cell. Int. J. Electrochem. Sci. 2013, 8, 10672-10687.

60. Kim, Y.-M.; Kim-Lohsoontorn, P.; Bae, J.-M. Characterization and Electrochemical Performance of Composite BSCF Cathode for Intermediate-temperature Solid Oxide Fuel Cell. J. Electrochem. Sci. Technol. 2011, 2, $32-38$. [CrossRef] 
61. Yaremchenko, A.A.; Patrakeev, M.V.; Naumovich, E.N.; Khalyavin, D.D. The $\mathrm{p}\left(\mathrm{O}_{2}\right)-\mathrm{T}$ stability domain of cubic perovskite $\mathrm{Ba}_{0.5} \mathrm{Sr}_{0.5} \mathrm{Co}_{0.8} \mathrm{Fe}_{0.2} \mathrm{O}_{3-\delta}$. Phys. Chem. Chem. Phys. 2018, 20, 4442-4454. [CrossRef]

62. Sahini, M.G.; Tolchard, J.R.; Wiik, K.; Grande, T. High temperature X-ray diffraction and thermo-gravimetrical analysis of the cubic perovskite $\mathrm{Ba}_{0.5} \mathrm{Sr}_{0.5} \mathrm{Co}_{0.8} \mathrm{Fe}_{0.2} \mathrm{O}_{3-\delta}$ under different atmospheres. Dalton Trans. 2015, 44, 10875-10881. [CrossRef]

63. Deganello, F.; Marcì, G.; Deganello, G. Citrate-nitrate auto-combustion synthesis of perovskite-type nanopowders: A systematic approach. J. Eur. Ceram. Soc. 2009, 29, 439-450. [CrossRef]

64. Tummino, M.L.; Liotta, L.F.; Magnacca, G.; Lo Faro, M.; Trocino, S.; Campagna Zignani, S.; Aricò, A.S.; Deganello, F. Sucrose-Assisted Solution Combustion Synthesis of Doped Strontium Ferrate Perovskite-Type Electrocatalysts: Primary Role of the Secondary Fuel. Catalysts 2020, 10, 134. [CrossRef]

65. Puleo, F.; Liotta, L.F.; Parola, V.; La Banerjee, D.; Martorana, A.; Longo, A. Palladium local structure of $\mathrm{La}_{1-x} \mathrm{Sr}_{x} \mathrm{Co}_{1-y} \mathrm{Fe}_{y-0.03} \mathrm{Pd}_{0.03} \mathrm{O}_{3-\delta}$ perovskites synthesized using a one pot citrate method. Phys. Chem. Chem. Phys. 2014, 16, 22677-22686. [CrossRef] [PubMed]

66. Fino, D.; Russo, N.; Saracco, G.; Specchia, V. The role of suprafacial oxygen in some perovskites for the catalytic combustion of soot. J. Catal. 2003, 217, 367-375. [CrossRef]

67. Liotta, L.F.; Ousmane, M.; Di Carlo, G.; Pantaleo, G.; Deganello, G.; Marcì, G.; Retailleau, L.; Giroir-Fendler, A. Total oxidation of propene at low temperature over $\mathrm{Co}_{3} \mathrm{O}_{4}-\mathrm{CeO}_{2}$ mixed oxides: Role of surface oxygen vacancies and bulk oxygen mobility in the catalytic activity. Appl. Catal. A Gen. 2008, 347, 81-88. [CrossRef]

68. Aliotta, C.; Liotta, L.F.; La Parola, V.; Martorana, A.; Muccillo, E.N.; Muccillo, R.; Deganello, F. Ceria-based electrolytes prepared by solution combustion synthesis: The role of fuel on the materials properties. Appl. Catal. B Environ. 2016, 197, 14-22. [CrossRef]

69. Lee, S.; Lim, Y.; Lee, E.A.; Hwang, H.J.; Moon, J.-W. $\mathrm{Ba}_{0.5} \mathrm{Sr}_{0.5} \mathrm{Co}_{0.8} \mathrm{Fe}_{0.2} \mathrm{O}_{3-\delta}$ (BSCF) and $\mathrm{La}_{0.6} \mathrm{Ba}_{0.4} \mathrm{Co}_{0.2} \mathrm{Fe}_{0.8} \mathrm{O}_{3-\delta}$ (LBCF) cathodes prepared by combined citrate-EDTA method for IT-SOFCs. J. Power Sources 2006, 157, 848-854. [CrossRef]

70. Chen, C.-H.; Chang, C.-L.; Hwang, B.-H. Electrochemical and microstructure characteristics of $\mathrm{Ba}_{0.5} \mathrm{Sr}_{0.5} \mathrm{Co}_{0.8} \mathrm{Fe}_{0.2} \mathrm{O}_{3-\delta}$ (BSCF) cathodes prepared by citrate precursor method for SOFCs. Mater. Chem. Phys. 2009, 115, 478-482. [CrossRef]

71. Tafaroji, S.; Farbod, M.; Kazeminezhad, I.; Kheirmand, M. Effect of pre-sintering temperature and ball-milling on the conductivity of $\mathrm{Ba}_{0.5} \mathrm{Sr}_{0.5} \mathrm{Co}_{0.8} \mathrm{Fe}_{0.2} \mathrm{O}_{3-\delta}$ as a cathode for solid oxide fuel cells prepared by sol-gel thermolysis method. Mater. Res. Express 2019, 6, 095522. [CrossRef]

72. Hieu, N.T.; Park, J.; Tae, B. Synthesis and characterization of nanofiber-structured $\mathrm{Ba}_{0.5} \mathrm{Sr}_{0.5} \mathrm{Co}_{0.8} \mathrm{Fe}_{0.2} \mathrm{O}_{3-\delta}$ perovskite oxide used as a cathode material for low-temperature solid oxide fuel cells. Mater. Sci. Eng. B 2012, 177, 205-209. [CrossRef]

73. Almar, L.; Störmer, H.; Meffert, M.; Szász, J.; Wankmüller, F.; Gerthsen, D.; Ivers-Tiffée, E. Improved Phase Stability and $\mathrm{CO}_{2}$ Poisoning Robustness of Y-Doped $\mathrm{Ba}_{0.5} \mathrm{Sr}_{0.5} \mathrm{Co}_{0.8} \mathrm{Fe}_{0.2} \mathrm{O}_{3-\delta}$ SOFC Cathodes at Intermediate Temperatures. ACS Appl. Energy Mater. 2018, 1, 1316-1327. [CrossRef]

74. Clematis, D.; Presto, S.; Carpanese, M.P.; Barbucci, A.; Deganello, F.; Liotta, L.F.; Aliotta, C.; Viviani, M. Distribution of Relaxation Times and Equivalent Circuits Analysis of $\mathrm{Ba}_{0.5} \mathrm{Sr}_{0.5} \mathrm{Co}_{0.8} \mathrm{Fe}_{0.2} \mathrm{O}_{3-\delta}$. Catalysts 2019, 9, 441. [CrossRef]

75. Yamada, I.; Odake, T.; Asai, K.; Oka, K.; Kawaguchi, S.; Wada, K.; Yagi, S. High-pressure synthesis of highly oxidized $\mathrm{Ba}_{0.5} \mathrm{Sr}_{0.5} \mathrm{Co}_{0.8} \mathrm{Fe}_{0.2} \mathrm{O}_{3-\delta}$ cubic perovskite. Mater. Chem. Front. 2019, 3, 1209-1217. [CrossRef]

76. Meffert, M.; Unger, L.; Störmer, H.; Sigloch, F.; Wagner, S.F.; Ivers-Tiffée, E.; Gerthsen, D. The effect of B-site $\mathrm{Y}$ substitution on cubic phase stabilization in $\left(\mathrm{Ba}_{0.5} \mathrm{Sr}_{0.5}\right)\left(\mathrm{Co}_{0.8} \mathrm{Fe}_{0.2}\right) \mathrm{O}_{3-\delta}$. J. Am. Ceram. Soc. 2019, 102, 4929-4942. [CrossRef]

77. Lee, S.; Lee, K.; Kang, S.; Kang, J.; Song, S.; Bae, J. Investigation of electrospun $\mathrm{Ba}_{0.5} \mathrm{Sr}_{0.5} \mathrm{Co}_{0.8} \mathrm{Fe}_{0.2} \mathrm{O}_{3-\delta}-\mathrm{Gd}_{0.1} \mathrm{Ce}_{0.9} \mathrm{O}_{1.95}$ cathodes for enhanced interfacial adhesion. Int. J. Hydrog. Energy 2018, 43, 21535-21546. [CrossRef]

78. Patra, H.; Rout, S.K.; Pratihar, S.K.; Bhattacharya, S. Effect of process parameters on combined EDTA-citrate synthesis of $\mathrm{Ba}_{0.5} \mathrm{Sr}_{0.5} \mathrm{Co}_{0.8} \mathrm{Fe}_{0.2} \mathrm{O}_{3-\delta}$ perovskite. Powder Technol. 2011, 209, 98-104. [CrossRef]

79. Toby, B.H. EXPGUI, a graphical user interface for GSAS. J. Appl. Crystallogr. 2001, 34, 210-213. [CrossRef] 
80. Presto, S.; Artini, C.; Pani, M.; Carnasciali, M.M.; Massardo, S.; Viviani, M. Ionic conductivity and local structural features in $\mathrm{Ce}_{1-x} \mathrm{Sm}_{x} \mathrm{O}_{2-x / 2}$. Phys. Chem. Chem. Phys. 2018, 20, 28338-28345. [CrossRef]

81. Raikova, G.; Carpanese, P.; Stoynov, Z.; Vladikova, D.; Viviani, M.; Barbucci, A. Inductance correction in impedance studies of solid oxide fuel cells. Bulg. Chem. Commun. 2009, 41, 199-206.

Publisher's Note: MDPI stays neutral with regard to jurisdictional claims in published maps and institutional affiliations.

(C) 2020 by the authors. Licensee MDPI, Basel, Switzerland. This article is an open access article distributed under the terms and conditions of the Creative Commons Attribution (CC BY) license (http://creativecommons.org/licenses/by/4.0/). 